Article

\title{
The Link between Board Structure, Audit, and Performance for Corporate Sustainability
}

\author{
Ovidiu-Constantin Bunget ${ }^{\mathbb{D}}$, Dorel Mates, Alin-Constantin Dumitrescu, Oana Bogdan * and \\ Valentin Burcă
}

Faculty of Economics and Business Administration, West University of Timișoara, 300115 Timișoara, Romania; ovidiu.bunget@e-uvt.ro (O.-C.B.); dorel.mates@e-uvt.ro (D.M.); alin.dumitrescu@e-uvt.ro (A.-C.D.);

burca_valentin@yahoo.com (V.B.)

* Correspondence: oana.bogdan@e-uvt.ro

Received: 2 September 2020; Accepted: 10 October 2020; Published: 13 October 2020

check for updates

\begin{abstract}
The economic and social transformations, the bankruptcies recorded, and the financial crisis affecting all economies have increased the interest for the corporate governance concept. Our intention in this paper was to study the impact of corporate governance attributes on performance given the information published by the entities listed on five stock exchanges from Europe, namely the main market from Bucharest Stock Exchange (BSE) in Romania, the Athens Stock Exchange(ATHEX) main market in Greece, Financial Times Stock Exchange 100 Index (FTSE 100) from Great Britain, Spanish Stock Exchange 35 Index (IBEX 35) from Spain, and Warsaw Stock Exchange 20 Index (WIG 20) from Poland, between 2016-2018. Through mathematical modeling and multiple linear regression, we aimed to determine the extent to which corporate governance characteristics, firm characteristics, industry and stock market fixed effects, and random effects influence the performance of 226 entities included in our sample. The empirical findings revealed that $\mathrm{CEO}$ duality, the number of non-executive directors and women on board, audit committee, and audit opinion influenced performance measured by the Return on Assets (ROA) and Return on Equity (ROE) indicators. The ideas highlighted and the results obtained in this research contribute to the literature that analyzes the extent to which an effective governance determines the increase in performance, needed for a sustainable development.
\end{abstract}

Keywords: corporate governance; audit; performance; sustainability; management board

\section{Introduction}

The failures that have taken place over time, such as the financial scandals generated mainly by the participants involved in the management of companies, such as Enron, WorldCom, Parmalat, or Gupta, and also the bankruptcies caused by the global financial crisis have led to declining the investors' confidence in the managers' abilities in leading large corporations. Thus, the academics' and practitioner's attention has been directed towards corporate governance and the study of the impact it has on the performance of companies.

Hence, the influence of corporate governance mechanisms on financial performance is a topic of great interest, fundamental in this field being the Cadbury Report, published in the UK in 1992 and the principles of corporate governance developed by the Organization for Economic Co-operation and Development (OECD) in 1999, documents that provide guidelines for improving how the listed entities are managed and controlled [1].

Over the last decade, researchers have made notable contributions to shaping theories about "the main determinant factors of the financial performance" reported by the economic entities [2,3]. Regardless of the calculation method, there are studies in the specialized literature that highlighted the particularities of the business model in obtaining positive financial performances [4]. But the results 
in this domain are not consistent, as there are also studies in which researchers could not identify a significant relationship between the elements of corporate governance and the financial performance expressed by various economic indicators, or their results show a negative relationship between variables. These differences can have several explanations, the results of the empirical research being largely influenced by the particularities of the model, the variables used, and the size of the analyzed sample [5].

However, the concepts, mechanisms, and tools of corporate governance have proven to be defining elements of the business model, given the scientific, systematic approach, centered on an efficient risk management, on increasing the effectiveness of control systems, and optimizing the processes and structures of informing, monitoring, and controlling the economic activity of entities.

In this context, the purpose of this study was to investigate the influence of corporate governance attributes on financial performance. Hence, the six research hypotheses of our study aimed to determine the extent to which: (1) board size, (2) the number of non-executive directors, (3) CEO duality, (4) gender diversity, namely the presence of women on the board of directors, (5) the existence of the audit committee, and (6) the qualified opinion expressed by the external auditor influenced firm performance. Our research was performed on two levels of analysis, namely at the level of the analysis of the corporate governance mechanisms and tools on the: (i) Return on Assets (ROA), and (ii) Return on Equity (ROE), the most used indicators for determining financial performance [6]. The novelty elements of this research were brought by the analysis regarding the existence of an industry-based pattern related to how corporate governance mechanism were defined and implemented in practice, as well as the study performed on five stock markets, including Bucharest Stock Exchange (BSE) and ATHEX, two stock markets with the highest growth in the world, taking into account the evolution of markets in 87 countries with available data [7].

The same statistics [7] place the stock exchanges from Great Britain, respectively the companies listed on FTSE 100 and Spain, namely the companies listed on IBEX 35 in the middle of the ranking. The last is the Polish Stock Exchange, the largest of the former communist countries in Eastern Europe, respectively the companies listed on WIG 20. Given this ranking, we believe that the sample included in our study is significant and relevant.

In order to achieve the objective and to identify the impact of corporate governance mechanisms on financial performance needed for a sustainable development, we included in our study 226 entities, listed on these five stock markets. The data necessary for the analysis, related to the board structure (size, number of non-executive directors, CEO duality, gender diversity), audit committee and external auditor's opinion, firm characteristics (Stock Market Value, Size, and Leverage) and the indicators used to measure performance (Net profit, Total Assets, Equity) were extracted manually from the Annual and the Sustainability Reports published by the analyzed entities between 2016-2018. The results add new evidence to that nowadays; corporate governance does not only mean maximizing the value of the company, but it also concerns its long-term development, taking into consideration the social, economic, and environmental sustainability.

Our paper is structured as follows: the first part, the specialized literature, presents the current state of knowledge in this field and the hypotheses underlying the research undertaken. The second part presents our study, highlighting and analyzing the estimated results of the regression models, and the last part of the paper reflects the conclusions, limits, and future directions of research.

\section{Literature Review and Hypothesis Development}

Corporate governance is a concept that has developed a lot in literature. According to the agency theory, the purpose of corporate governance is to maximize the value of the firm, being a tool for monitoring, controlling, and optimizing the procedures used by shareholders to ensure that their interests and goals are met [6]. Separating shareholders from managers is particularly important when the interests of shareholders are different from those of the entity's executive management, the principles of corporate governance acting in this case as a bridge between them. 
Over time, the concept of corporate governance has expanded out of the desire to ensure the sustainable development of companies and the the increase of transparency and social responsibility, given the maximization of the interests of all the parties involved in the company's business and not just of its owners. In recent studies [8,9], corporate governance is defined as a set of mechanisms that coordinate and balance the interests of all stakeholders, whether we talk about shareholders, stakeholders, or other interested parties and contribute to maximizing their benefits.

The performance is a primary objective of economic entities, and the relationship between performance and how entities are managed and controlled represents a debated topic in the specialized literature in order to determine and analyze the correlation between corporate governance and the financial performance measured by different economic indicators.

In the study performed, Siminica et al. [6] analyzes the interdependencies between the dimensions of social responsibility (economic, environmental, and social), financial performance (measured by the ROA and ROE indicators) and corporate governance through a structural equation modeling technique, taking into account a sample consisting of 614 entities in the European Economic Area. The research results reflect that corporate governance has a positive impact on all model variables, both as a direct and indirect influence factor.

The empirical research performed by Zhang et al. [10] by using the hierarchical regression method, on a sample of 433 entities listed on the Shanghai and Shenzhen stock exchanges between 2007-2017 also reflects the positive influence of corporate governance on firm performance. Pillai and Al-Malkawi [4], in the study performed on 349 listed entities, identifies that certain corporate governance attributes, such as audit type, board size, and leverage, significantly influence the performance for the vast majority of entities included in the sample.

However, there are also studies that have not identified a significant influence of corporate governance attributes on performance. An example in this case is the research performed by Al-ahdal et al. [11] on 106 entities between 2009-2016. Its results reveal that board accountability does not significantly influence firm performance measured by the ROE and Tobin's Q indicators. Zabri et al. [12], in the analysis on a sample of 100 listed entities, identifies that board size has a significantly weak negative relationship with ROA and is insignificant to ROE. Another result of his study reflects that there are no relationships between board independence and firm performance.

The research performed by Yameen et al. [13] on 39 entities listed between 2013-2016 identifies, through the ordinary least square regression method, that board size and audit committee size negatively influence the performance measured by the ROA and ROE indicators, considered accounting proxies within the model. By measuring performance through Tobin's $Q$ indicator, considered a marketing proxy, the results reveal that board size and audit committee size positively influence performance.

In terms of the board size, there are studies showing that a large board can significantly influence performance. If the company has a unitary board of directors, we talk about the existence of a Board of Directors consisting of executive, non-executive and independent directors, out of whom one has the role of Chairman. The role of the Board is to manage the company, to set strategic development objectives, to provide the resources necessary to meet the assumed objectives, and to evaluate the activity of the executive management. In the dual board system, there are two separate structures: the Supervisory Board, consisting exclusively of non-executive directors, and the Management Board, consisting exclusively of executive directors. The role of the Supervisory Board is to ensure the entity's strategy as well as to appoint, supervise, and advise the members of the Management Board. The Management Board is responsible for the day-to-day management of the entity, and its members are jointly liable to the Supervisory Board for the executive management of the company. Given agency theory, a large board can reduce managerial dominance, being effective in reducing potential conflicts of interest [14]. Human resources can create added value for the company, due to the knowledge, skills, and diversity of directors, skills that can be used for the company's benefit, if there is a larger board [15]. From this perspective, we may state that a large board can positively influence firm performance. This hypothesis was validated by researchers such as Hu and Loh [16], Bae et al. [17], 
Fernandez-Gago et al. [18], and Hoti and Dermaku [19]. Georgantopoulos and Filos [20], through GMM models, also validates the hypothesis that increasing the number of members on the board improves performance. Zhou et al. [21], based on a sample of entities listed on the ATHEX between 2008-2012, identifies that entities with larger boards are more efficient. Adams and Mehran [22] consider that a large number of board members can cope more easily with the problems that may threaten the smooth unfolding of the companies' activity, given their capabilities and the pluralism of opinions. However, there are researchers who argue the opposite, namely that smaller boards improve performance because they are more effective in achieving performance, emphasizing the idea that communication deficiencies, subjectivism, and the variety of opinions in decision making are the main issues of larger boards. Examples in this case are the studies performed by Franken and Cook [23], Kim et al. [5], Felicio et al. [24], and Garefalakis et al. [25]. Therefore, we consider that board size has a significant impact on financial performance and the first hypothesis that we tested was:

Hypothesis 1 (H1). The board size influences firm performance.

The entities' board of directors consists of executive, non-executive, and independent directors. The executive directors are involved in the entity's management and make decisions on its behalf. The non-executive directors play an important role in governance, their objectivity being essential to the shareholders, since their role is to supervise the executive directors and to inform the shareholders whether their interests are protected or not. An important governance structure is represented by the independent directors on the Board. In order to maintain their independence, the latter have to meet certain essential criteria, among which the following: they were not employees or directors of the company, they did not receive additional payment or other benefits, they are not majority shareholders of the company, and they did not have business relations with the entity in which they intend to become independent directors or with other entities it controls. The rules of good corporate governance advise entities to have an approximately equal number of non-executive and executive directors. Regarding the impact of the percentage of non-executive and independent directors on the entities' performance, previous studies in specialized literature reflects mixed results. Dahya and McConnell [26] finds that increasing the number of non-executive directors increases performance. Boitan and Nitescu [27] also reveals that, as a consequence of the increased board independence, represented by a large share of independent members in total board members, a positive and significant influence is registered by banking system's profitability indicators (ROA and ROE). The same result is reached by Cornett et al. [28], by studying the impact of governance attributes on performance, taking into account a sample of companies included in the S\&P100 index. On the other hand, Coles et al. [29] and Kiel and Nicholson [30] identify a negative relationship between the two variables, which may reflect that the independent members cannot effectively control the leaders. We therefore believe that there is a positive relationship between the number of non-executive directors and the entity's financial performance. The second hypothesis tested was:

Hypothesis 2 (H2). The number of non-executive directors influences firm performance.

CEO duality is another corporate governance attribute whose influence on performance has generated debates in literature. CEO duality appears when the same person holds both the position of CEO and that of chairman of the board. There are researchers, like Nazar [31] and Grose et al. [32] who claim and demonstrate that CEO duality is negatively associated with performance, given that the power is in the hands of a single person, which allows the CEO to control managerial information. On the other hand, Pillai and Al-Malkawi [4], in the study performed, identifies that CEO duality positively influences financial performance in the case of family businesses and has a negative influence among other entities. The results of the research performed by Naciti [33] and Garefalakis et al. [25] reveal that the separation of the two positions increases performance. On the other hand, the empirical analysis performed by Elsayed [34] identifies a negative impact of duality on the performance of the 
sampled entities and recommends separating these roles because duality can harm the interests of minority shareholders and can reduce the independence of the board of administration. If we talk about family ownership, no dominating group exists on the board, and family members are keenly interested in enhancing financial performance [35]. We therefore believe that CEO duality has a significant impact on financial performance measured through ROA and ROE indicators. The third hypothesis tested was:

Hypothesis 3 (H3). CEO duality influences firm performance.

Equal opportunities and the role of women in sustainable development have become a topic of interest, especially due to the resolution formulated by the United Nations in September 2015 which states that gender equality should be one of the worldwide goals of sustainable development over the next 15 years [36]. As for the number of women on the board and their influence on improving firm performance, the research undertaken does not show consistent results. Thus, in the study performed on 343 entities listed between 2012-2016, Ionascu et al. [37] confirms previous concerns related to the endogeneity of gender diversity variables in firm performance regression analysis and shows that, on average, gender diversity does not have a significant impact on performance. The same result is reached by Wang [38], who, after the study performed, states that increasing the number of female directors does not guarantee an increased performance. Carter et al. [39], on the other hand, states that the estimation of fixed effect regression equations indicates a positive and significant relationship between both the number of women on the board and the number of ethnic minorities on the board and the ROA.

We therefore consider that there is a positive relationship between the number of women on the Board of Directors and the entity's performance. The fourth hypothesis tested was:

Hypothesis 4 (H4). Gender diversity, namely the inclusion of women on the board, influences firm performance.

For corporate governance to be considered effective, it should provide appropriate control mechanisms that intervene in critical situations and protect the interests of all categories of users [40]. Thus, the audit committee, composed of non-management members of a company's board [41], represents one of the main monitoring mechanisms in corporate governance, having the role of regulating conflicts of interest, reducing agency costs, reviewing compliance with applicable laws and regulations, managing risk, and evaluating the corporate governance process [42]. In specialized literature, the research on the impact that the existence of the audit committee has on performance does not reflect consistent results. Thus, Aldamen et al. [43] states that longer serving chairs of audit committees negatively impacts performance. Model 5 of the study performed by Yameen et al. [13], on the other hand, identifies, in contrast with the predicted result of the study, a direct relationship between the size of the audit committee and performance, namely the increase in the number of members of the audit committee by one unit increases the ROA by 26 percent. Correlating with the ROE, the results from Model 4 reflect a negative relationship between the two variables. Laing and Weir [44], in the 1999 study, identified a positive relationship between the existence of the audit committee and the performance measured by the ROA, and later, in 2002, Weir and Laing [45] concluded that the existence of the audit committee did not influence the performance measured by the Tobin's $Q$ indicator. We therefore consider that there is a positive relationship between the existence of the Audit Committee and the entity's performance. The fifth hypothesis tested was:

Hypothesis 5 (H5). The existence of the audit committee influences firm performance.

The relationship between corporate governance and the external audit can be best explained through the two acknowledged theories in the field of governance, namely Agency and Stakeholder's theories. The External audit improves the quality of the information provided and represents a solution 
for agency theory [46]. Within companies, the associates have access to the information communicated by managers, and the informational asymmetry between the two parties can generate conflicts because, most of the times, managers have a privileged position. Through the external audit, the risk of presenting distorted information is reduced and shareholders can make optimal decisions, based on credible information. The stakeholder's theory no longer concerns only the relationship between the manager and the shareholder, but it takes into account the interests of all stakeholders and determines changes regarding the role of the auditor. The audit is not limited to reassuring shareholders of the reliability and accuracy of the accounting information disclosed by managers, but it evolves towards an audit focused on the expectations of all stakeholders [47]. Georgantopoulos and Filos [20], through the GMM estimations, identifies a positive but weak relationship between the auditing of financial statements by a Big4 company and performance. This result suggests that the certification provided by a well-reputed and creditable auditor in the field may increase investor confidence and equally increase financial performance. Conheady et al. [48] also presents a positive and significant relationship between the existence of a Big4 company and the performance measured by the Tobin's $Q$ indicator. In the research hypothesis, Pillai and Al-Malkawi [4] starts from the idea of a positive relationship between audit and performance, the research results confirming a significant but negative relationship determined, mainly, by the immaturity of the CSR concept and by the auditors' lack of experience. We believe that the qualified opinion issued by the external auditor on the financial statements that present fairly, in all material aspects, the position, performance, and cash flows reinforces the confidence of the current and potential investors in the company's management and also reflects credibility and transparency, which are essential elements for the sustainable development of any economic entity. Therefore, we propose this sixth research hypothesis:

Hypothesis 6 (H6). The qualified opinion expressed by the external auditor influences firm performance.

Given the inconclusive results in the specialized literature concerning the impact of corporate governance attributes on financial performance, we support the need for further research in this area.

\section{Data and Methodology of Research}

\subsection{Data}

The sample of our study consisted of 226 entities listed on five stock markets, namely the Bucharest Stock Exchange (BSE) [49], the ATHEX main market [50], FTSE 100 [51], IBEX 35 [52], and WIG 20 [53], including two attractive markets for potential investors, namely Romania and Greece. According to Eurostat data [54], between 2008-2019, Romania and Greece registered a growth rate of GDP per capita in PPS higher than other EU member states. The capital contribution and a solid fiscal governance framework is an engine of growth of the economy that can equally bring the know-how and the transfer of technology, which are indispensable for the increase in competitiveness of companies [55]. We can conclude that such investments are requirements for the sustainable development of the society, both from an economic and a social perspective.

The source of the data was represented by the information published in the Annual and Sustainability Reports by the listed entities that registered profit between 2016-2018. For the entities listed on the ATHEX, WIG 20, and IBEX 35 market, we included an additional criterion besides profit, namely the publication of the reports in English. Thus, we kept 58 entities listed on the Bucharest Stock Exchange, 39 entities listed on the ATHEX main market, 82 entities listed on FTSE 100, 31 companies listed on IBEX 35, and 16 entities included in WIG 20. Taking into account that the entities listed on FTSE 100 express the results obtained in pounds, the ATHEX and IBEX market express the results obtained in euros, the entities listed on the BSE in lei and the companies listed on WIG 20 in Polish zloty, in order to ensure data comparability, the values expressed were converted into euros. 


\subsection{Methodology of Research}

Given the research presented in literature, our analysis used accounting based measures such as the ROA and the ROE, these dependent variables, being presumed to offer more objective indications of the companies' recent and past present performance" [37].

In our research, we considered as explanatory variables important corporate governance attributes such as board structure (size, number of non-executive directors, CEO duality, gender diversity, namely women on board), audit (audit committee and external auditor's opinion), but also control variables such as Stock Market Value, Size and Leverage, related to firm characteristics. For the comparability of the results, the values of Stock Market Value and those expressing firm size were measured using a natural logarithm of the total assets, following Masud et al. [56]. We also included in the analysis the industry and stock market fixed effects and random effects, in order to determine their influence on performance and to reduce the shock of unnoticed particularities of the industry or other macroeconomic factors.

The regression model used to test the hypotheses has the following configuration:

$$
\begin{gathered}
\text { Performance }_{i}=\beta_{0}+\beta_{1} \text { Board_size }_{i}+\beta_{2} \text { Non_ex }_{i}+\beta_{3} \text { CEO_duality }_{i}+\beta_{4} \text { Women }_{-} \\
\text {on Board }_{i}+\beta_{5} \text { Audit Committee }_{i}+\beta_{6} \text { External Auditor opinion }_{i}+\beta_{7} \text { Control } \\
\text { variables }_{i}+\beta_{8} \text { Industry dummy }_{i}+\beta_{9} \text { Stock market dummy }_{i}+\varepsilon_{I}
\end{gathered}
$$

where

- Performancei-expressed by ROA and ROE indicators;

- $\quad \beta_{0}$-quantifies all factors that were not taken into account by using an explanatory variable in the analyzed model;

- $\beta_{1}, \beta_{2}, \beta_{3}, \beta_{4}, \beta_{5}, \beta_{6}, \beta_{7}, \beta_{8}, \beta_{9}-$ parameters specific to each influencing factor;

- $\varepsilon_{\mathrm{i}}$-reflects the residual term quantifying the influence of random factors or other factors that were not included in the analysis

\begin{tabular}{|c|c|c|c|}
\hline Category & Sub-Category & Name & Description \\
\hline Dependent variables & & Return on Assets (ROA) & $\begin{array}{l}\text { own calculation after the companies' Annual and Sustainability reports, } \\
\text { calculated using net income divided by the total assets, as an arithmetic } \\
\text { mean of the values recorded in the period 2016-2018 }\end{array}$ \\
\hline \multirow{7}{*}{ Explanatory variables } & \multirow{3}{*}{ Board structure } & Board size & $\begin{array}{l}\text { represents the total number of board members for the entities listed on } \\
\text { each of the two stock exchanges analyzed }\end{array}$ \\
\hline & & CEO Duality & $\begin{array}{l}\text { represents the CEO duality for the entities listed on each of the two } \\
\text { stock exchanges analyzed that takes the value } 1 \text { if the CEO is also } \\
\text { chairman and the value } 0 \text { otherwise; }\end{array}$ \\
\hline & & Women on Board & $\begin{array}{l}\text { represents the number of female members on the board for the entities } \\
\text { listed on each of the two stock exchanges analyzed }\end{array}$ \\
\hline & \multirow{3}{*}{$\begin{array}{l}\text { Firm characteristics } \\
\text { (control variables) }\end{array}$} & Stock market value & $\begin{array}{l}\text { own calculation after the companies' Annual and Sustainability reports, } \\
\text { based on share price and number of shares }\end{array}$ \\
\hline & & Size & $\begin{array}{l}\text { reflects the size of the companies listed on the two stock exchanges, } \\
\text { using natural logarithm of the total assets as an indicator }\end{array}$ \\
\hline & & Leverage & $\begin{array}{l}\text { own calculation after the companies' Annual and Sustainability reports, } \\
\text { calculated using the ratio of total liabilities divided by total equity }\end{array}$ \\
\hline & Fixed effects & $\begin{array}{c}\text { Industry } \\
\text { Stock market }\end{array}$ & $\begin{array}{l}\text { variables used to reduce the shock of unobserved features of the } \\
\text { industry or other macroeconomic factors }\end{array}$ \\
\hline
\end{tabular}

The summary of the variables we used can be found in Table 1.

Table 1. Summary of variables. 
Our research was performed through econometric modeling in the EViews program and the results obtained and their interpretation are reflected in the next section.

\section{Results and Discussion}

\subsection{Descriptive Statistics}

Descriptive statistics included in the regression models are presented in Table 2. Our results show that the average return on assets is $6.4 \%$. For entities where the position of executive director is not separate from that of chairman of the Board of Directors, the average ROA is $6.55 \%$ and for entities where these functions are separate, the average return is $8.13 \%$. The average return on equity (ROE) is $15.84 \%$, higher than the ROA for the entities included on our sample. For companies where the two functions are not separate, the average ROE is $13.71 \%$ and for entities with no duality, the average return on equity is $16.2 \%$.

Table 2. Descriptive statistics for the companies included in our sample.

\begin{tabular}{ccccc}
\hline & Minimum & Maximum & Mean & Std. Deviation \\
\hline Performance Variables & & & & \\
\hline ROA & 0.001 & 0.377 & 0.064 & 0.054 \\
ROE & 0.001 & 0.966 & 0.158 & 0.155 \\
\hline Corporate Governance & & & \\
Variables & & & & \\
\hline Board size & 3 & 18 & 9.177 & 3.350 \\
Non-executive members & 0 & 13 & 6.221 & 2.541 \\
CEO Duality & 0 & 1 & 0.146 & 0.354 \\
Women on board & 0 & 6 & 2.150 & 1.536 \\
External auditor opinion & 0 & 1 & 0.973 & 0.161 \\
Audit Committee & 0 & 1 & 0.956 & 0.206 \\
\hline Control Variables & & & & \\
\hline Company size & 13.83 & 28.65 & 21.58 & 3.03 \\
Stock market value * & 15.96 & 25.56 & 21.51 & 2.26 \\
Leverage & 0.004 & 193.29 & 4.028 & 14.75 \\
\hline
\end{tabular}

* to ensure data comparability, we used natural logarithm to express the value of the variables Company' size and Stock market value.

The average number of members of the Board of Directors is 9. Out of the 226 entities under analysis, 12 companies have the smallest number of persons on the board, namely 3 members and 2 entities present a board of 18 directors, the maximum value found in the study. In Figure 1, we observe the number of persons on the board seem to be relatively the same between different sectors of activity. However, in case of the services sector the number of board members is the highest, especially in case of companies listed on IBEX stock market.

The average number of non-executive directors on the board is 6, which confirms the observance of the corporate governance principles recommending that the majority of the members of the Board of Directors should not hold an executive function. Out of the 226 entities, there is also a case where the Board does not include any non-executive director, thus resulting in the minimum value 0 of the descriptive statistics, but also cases where all the directors of the board are non-executive, the maximum value of the indicator being 14. In Figure 2, we observe the number of non-executive's directors on the board is relatively similar between sectors of activity. Most interested companies, on following this corporate governance principle, seem to be companies listed on IBEX and FTSE stock markets, which have a better regulatory basis related to corporate governance mechanisms. However, as shown in case of board size, we observe that companies operating in the financial services area prefer to consider a higher number of non-executive members on the board than the other areas of activity. 


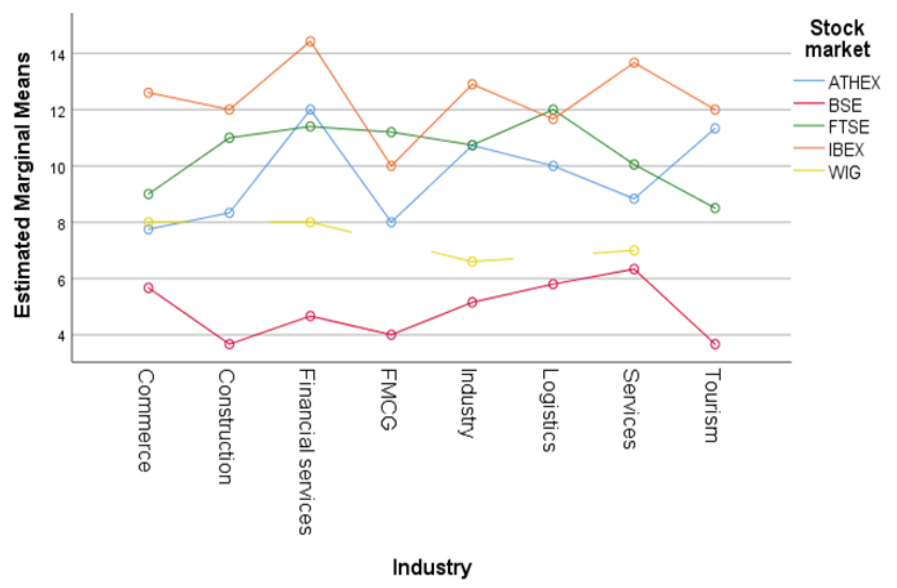

Figure 1. Marginal means of board size, differentiated by stock market and area of activity.

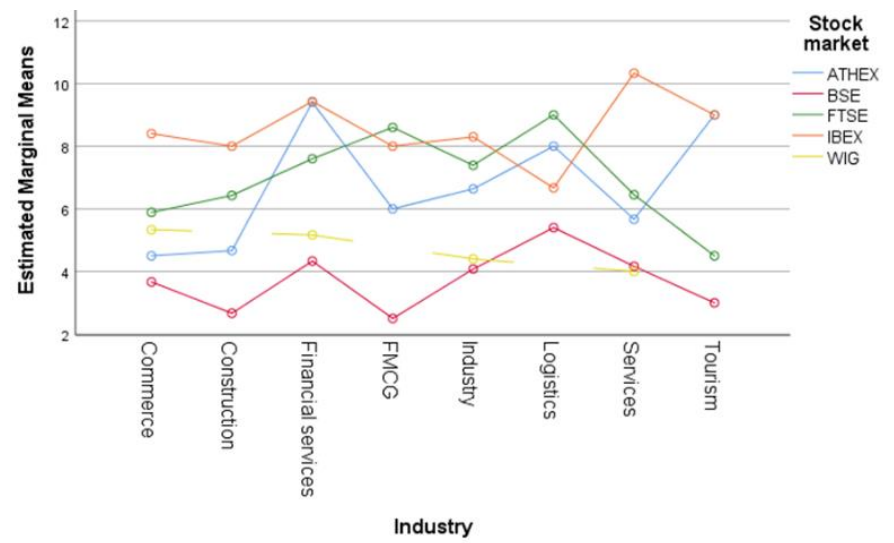

Figure 2. Marginal means of non-executive directors on board, differentiated by stock market and sector.

Out of the 226 companies under analysis, in 193, the CEO is separate from the chairman, which means a percentage of $85.4 \%$, thus confirming general recommendations of stock market codes of corporate governance. In 33 entities, the two functions are the same, which means a percentage of $14.6 \%$ out of the investigated sample. From those 33 entities, 27 of them are listed on BSE and ATHEX stock markets, while on the other stock markets analyzed, this principle seems to be extremely important, as no more than $15 \%$ from the companies listed on those markets have the CEO of the company as chairman of the board.

In the vast majority of cases, $97.35 \%$, representing 220 entities out of the 226 under analysis, the opinion expressed by the external auditor is that the financial statements reflect a faithful image of the position and financial performance and cash flows. The only six entities having an auditor opinion with reserves are listed on ATHEX and BSE stock markets.

As for gender diversity on the Board of Directors, the analysis reveals that out of the 226 companies, 44 have no female director, while only two entities, listed on FTSE, have 6 female directors, which represents the maximum value reached in the investigated sample, as described in Figure 3. Therefore, the number of women on board which represent about $22.22 \%$ from the board size, is still very small, compared to the objective of $40 \%$ set-up by EU Commission [36].

Out of the 226 entities included in our study, the vast majority, namely 216 entities, which represent $95.58 \%$, comply with the provisions of the general Corporate Governance Code principles regarding the setting-up of the Audit Committee. Entities with no Audit Committee established on the organizational chart, are found listed on BSE stock market.

Our analysis underlines a significant spread on the ratios describing the control variables considered in our study. The sample considered in the study consist of companies varying in size, as the logarithm of the total assets varies from 13.83 to 28.65 , with cases higher than the mean exceeding 
$57.62 \%$ from the sample, implying the majority of the companies considered are of higher size. More than $61.95 \%$ from the sample considered in the study have a market value higher than the mean value describing the whole sample, that show our sample consists of highly capitalized companies. Related to leverage, the composition of our sample reveal the fact that companies considered are highly indebted as more than $56.64 \%$ from the companies reported level of financial leverage of more than 5 , with potential constraints implications on financial performance that could be monitored by credit institutions as covenants agreed in the credit contract. Companies operating in the financial services sector disclose the highest values.

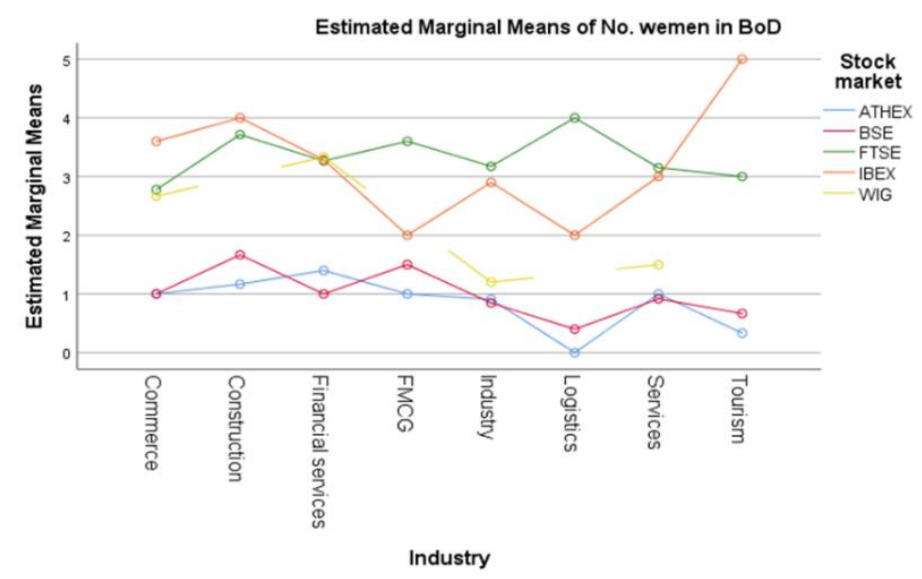

Figure 3. Marginal means of number of women on board, differentiated by stock market and sector.

Comparing the companies analyzed along area of activity and stock market where they are listed, we notice in Figures 4 and 5 that, on average, companies listed on the BSE and IBEX have a higher spread on financial performance led by the specific of the area of activity. As expected, it seems that companies listed on FTSE report higher financial performance. It seems that companies listed on ATHEX disclose lower financial performance than the other companies do. A higher difference between stock markets is observable in case of ROE as it is directly influenced by companies' financing policies on a short term. On the other side, the ROA ratio focuses more on the operations that are affected only by strategic decisions, but on medium to long term. The less performant area of activity seems to be the sector of financial services, except the case of BSE listed companies, which show the contrary.

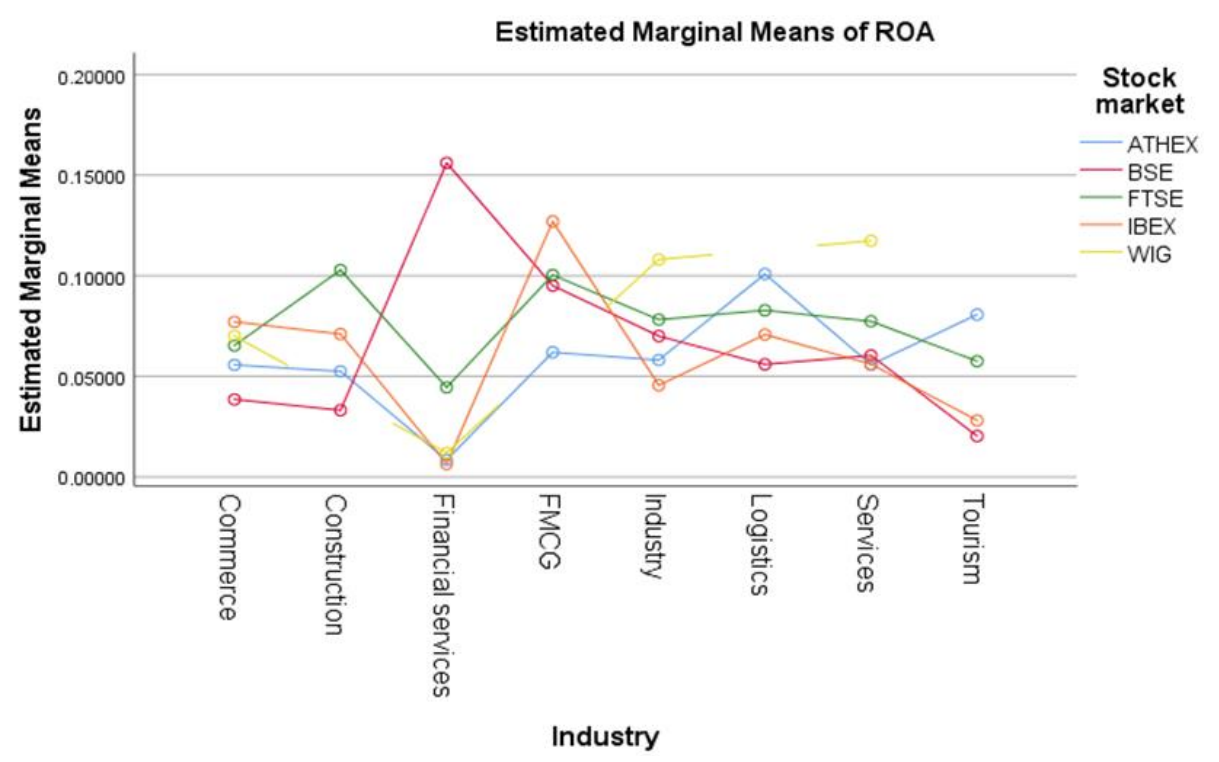

Figure 4. Marginal means of ROA, differentiated by stock market and area of activity. 


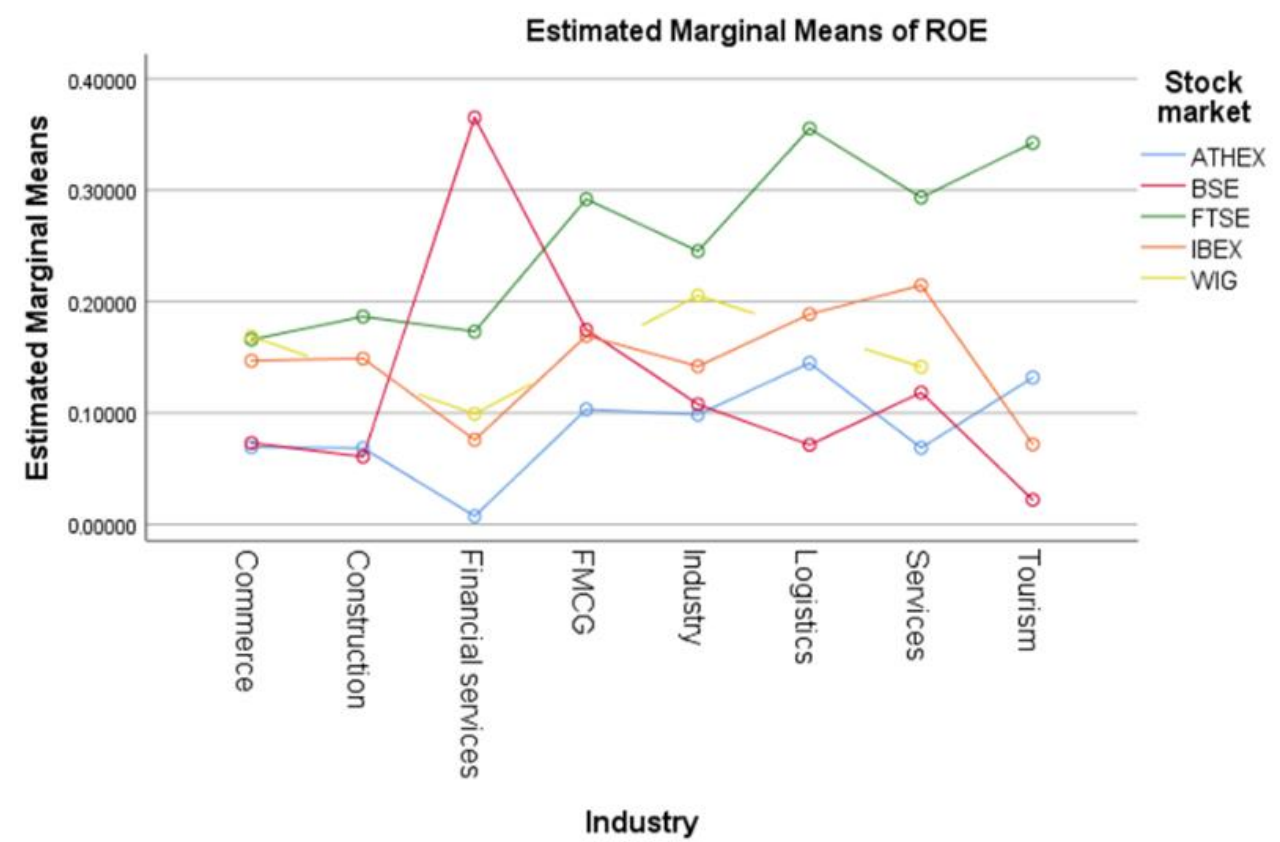

Figure 5. Marginal means of ROE, differentiated by stock market and area of activity.

Our approach to measure stock market factor and area of activity factor effects on financial performance start from the results obtained running ANOVA test, as described in Table 3.

Table 3. ANOVA descriptive statistics.

\begin{tabular}{|c|c|c|c|c|c|c|}
\hline & \multicolumn{3}{|c|}{ Area of Activity Impact } & \multicolumn{3}{|c|}{ Stock Market Impact } \\
\hline & df & $\mathbf{F}$ & Sig. & df & F & Sig. \\
\hline \multicolumn{7}{|c|}{ Financial Performance Variables } \\
\hline ROA & 7 & 2.267 & 0.030 & 4 & 1.657 & 0.161 \\
\hline ROE & 7 & 1.003 & 0.430 & 4 & 10.56 & 0.000 \\
\hline \multicolumn{7}{|l|}{ Corporate Governance Variables } \\
\hline Board size & 7 & 1.809 & 0.087 & 4 & 85.52 & 0.000 \\
\hline Non-executive members & 7 & 2.147 & 0.040 & 4 & 32.32 & 0.000 \\
\hline CEO Duality & 7 & 0.997 & 0.434 & 4 & 7.574 & 0.000 \\
\hline Women on board & 7 & 2.697 & 0.011 & 4 & 56.93 & 0.000 \\
\hline External auditor opinion & 7 & 2.384 & 0.023 & 4 & 3.037 & 0.018 \\
\hline Audit Committee & 7 & 1.555 & 0.150 & 4 & 6.48 & 0.000 \\
\hline \multicolumn{7}{|l|}{ Control Variables } \\
\hline Stock market value & 7 & 2.615 & 0.013 & 4 & 83.76 & 0.000 \\
\hline Company size & 7 & 8.010 & 0.000 & 4 & 64.31 & 0.000 \\
\hline Leverage & 7 & 4.008 & 0.000 & 4 & 1.964 & 0.101 \\
\hline
\end{tabular}

Our results underline a significant impact generated by the specific area of activity in case of: board size (Sig.Board size $=0.087<10 \%$ ), number of non-executive members in the board (Sig.Non ex $=$ $0.04<5 \%$ ), number of women on the board (Sig.women bod $=0.011<5 \%$ ), and external audit opinion $($ Sig.aud op $=0.030<5 \%)$. On the other side, our results underline significant impact generated by stock markets factor in case of all corporate governance variables, with a significance level of $1 \%$. 
Those results determine us to analyze more in depth if either fixed/random effects influence the regression estimators.

\subsection{The Influence of Corporate Governance Mechanism on Performance Measured Through the ROA Indicator}

First, we studied the influence of corporate governance mechanisms on performance measured through the ROA indicator. The results obtained are presented in the next table (Table 4).

Table 4. The econometric analysis of corporate governance mechanisms on the ROA.

\begin{tabular}{|c|c|c|c|c|c|}
\hline \multicolumn{6}{|c|}{ Dependent Variable } \\
\hline \multicolumn{6}{|c|}{ ROA } \\
\hline & & & Models & & \\
\hline Determinant Variables & (1) & (2) & (3) & (4) & (5) \\
\hline Board size & $\begin{array}{c}-0.005^{* *} \\
(0.002)\end{array}$ & $\begin{array}{l}-0.001 \\
(0.002)\end{array}$ & $\begin{array}{c}-0.004^{* *} \\
(0.002)\end{array}$ & $\begin{array}{l}-0.006 \\
(0.003)\end{array}$ & $\begin{array}{c}0.000 \\
(0.002)\end{array}$ \\
\hline Non-executives members & $\begin{array}{c}0.000 \\
(0.003)\end{array}$ & $\begin{array}{l}-0.002 \\
(0.002)\end{array}$ & $\begin{array}{c}0.000 \\
(0.003)\end{array}$ & $\begin{array}{c}0.001 * * \\
(0.003)\end{array}$ & $\begin{array}{l}-0.003 \\
(0.002)\end{array}$ \\
\hline CEO duality & $\begin{array}{c}0.022^{* *} \\
(0.010)\end{array}$ & $\begin{array}{c}0.023^{* *} \\
(0.009)\end{array}$ & $\begin{array}{c}0.019 * * \\
(0.010)\end{array}$ & $\begin{array}{c}0.025^{* *} \\
(0.011)\end{array}$ & $\begin{array}{c}0.022 \text { ** } \\
(0.009)\end{array}$ \\
\hline Women on Board & $\begin{array}{c}0.007^{* *} \\
(0.003)\end{array}$ & $\begin{array}{c}0.005^{* *} \\
(0.003)\end{array}$ & $\begin{array}{l}0.008 * \\
(0.003)\end{array}$ & $\begin{array}{c}0.003 \\
(0.003)\end{array}$ & $\begin{array}{c}0.006^{* *} \\
(0.003)\end{array}$ \\
\hline Audit Committee & $\begin{array}{c}0.036^{* *} \\
(0.018)\end{array}$ & $\begin{array}{c}0.019 * * \\
(0.016)\end{array}$ & $\begin{array}{c}0.045^{* *} \\
(0.018)\end{array}$ & $\begin{array}{c}0.032 \text { *** } \\
(0.018)\end{array}$ & $\begin{array}{c}0.031^{* *} \\
(0.016)\end{array}$ \\
\hline Audit Opinion & $\begin{array}{c}0.037^{* * *} \\
(0.022)\end{array}$ & $\begin{array}{c}0.047 \\
(0.019)\end{array}$ & $\begin{array}{l}0.051 \text { ** } \\
(0.023)\end{array}$ & $\begin{array}{c}0.035 \\
(0.022)\end{array}$ & $\begin{array}{l}0.063 * \\
(0.019)\end{array}$ \\
\hline Stock market value & - & $\begin{array}{l}0.021 * \\
(0.003)\end{array}$ & - & - & $\begin{array}{l}0.023 * \\
(0.003)\end{array}$ \\
\hline Size & - & $\begin{array}{c}-0.017 \text { * } \\
(0.002)\end{array}$ & - & - & $\begin{array}{c}-0.019 * \\
(0.002)\end{array}$ \\
\hline Leverage & - & $\begin{array}{c}-0.0002 \\
(0.000)\end{array}$ & - & - & $\begin{array}{c}-0.0002 \\
(0.000)\end{array}$ \\
\hline \multicolumn{6}{|c|}{ Model Validation } \\
\hline Sample size & 226 & 226 & 226 & 226 & 226 \\
\hline Fixed effects-industry & $\mathrm{N}$ & $\mathrm{N}$ & $\mathrm{Y}$ & $\mathrm{N}$ & $\mathrm{Y}$ \\
\hline Fixed effects—stock market & $\mathrm{N}$ & $\mathrm{N}$ & $\mathrm{N}$ & $\mathrm{Y}$ & $\mathrm{N}$ \\
\hline $\mathrm{R}^{2}$ adjusted & $5.81 \%$ & $32.89 \%$ & $10.08 \%$ & $6.35 \%$ & $35.49 \%$ \\
\hline Durbin-Watson stat & 1.90 & 2.03 & 1.87 & 1.97 & 2.03 \\
\hline $\mathrm{F}$ & 3.31 & 13.25 & 2.941 & 2.525 & 8.735 \\
\hline$p$ & 0.0039 & 0.0000 & 0.0006 & 0.0068 & 0.0000 \\
\hline
\end{tabular}

Notes: Standard errors are in parantheses. * significant for $1 \%$ significance level; ${ }^{* *}$ significant for $5 \%$ significance level; ${ }^{* * *}$ significant for $10 \%$ significance level.

In Table 4, we notice that, regardless of the specifics of the stock markets, or the specifics of the area of activity, the board of director's size determines a negative marginal effect on the return on assets engaged in the economic activity, as the marginal regression coefficient of -0.005 is statistically significant with a significance level of 5\%, in line with the result obtain by Perrini [57].

Thus, an oversized board of directors makes it difficult to take decisions on strategic investment projects, which is why the allocation of the available assets is adversely affected by a delayed decision or even by the dropping of a profitable investment project, but probably on a long-term level. However, firms' characteristics, such as company size and stock market value seem to have a higher influence on ROA, as reflected in model (2), since large companies have the "luxury" to invest in modern 
technologies and experiment new trends [58]. A marginal effect of board size on ROA is not statistically significant, while marginal effect of stock market value and company size are valid, with a significance level of $5 \%$. The results emphasize the fact that capital market's voice is powerful, as the positive stock market value marginal effective on ROA exceed the negative marginal effect generated by the company size. At the same time, we note that the specifics of the industry reduce the negative marginal effect of the board of director's size, given that the level of the regression coefficient increases to -0.004 , with a significance level of $5 \%$. This evolution leads us to the differences existing between guidelines existing on different areas of activity. It is easily deductible from Figure 1, where it can be seen that companies operating on FMCG area have a lower board size, compared with companies providing financial services.

However, this factor does not cause a statistically significant marginal effect when looking for stock markets specific effects, given that the probability of the $t$-test performed on the regression coefficient in model (5), which exceeds the minimum accepted significance level of $10 \%$. However, models (1) to (5) show the model is statistically significant as the probability of $\mathrm{F}$ test is under the $1 \%$ significance level.

Regarding the impact of the number of non-executive members on the board of directors, we notice a positive marginal effect on the return on assets engaged in the operational activity of the economic entities, as described in model (4). These results are contradictory to those revealed in the study of Linck et al. [59], which identify the existence of a negative relationship between firm performance and the percentage held by the independent directors, given their inability to control the executive management. However, we notice that this effect is more visible only for some stock markets, as model (4) controls for fixed effects generated by the specific of stock markets included in our sample.

The implications of the CEO assuming the role of chairman of the board of directors reveal a positive relationship on the ROA, regardless of the effects of the industry or the effects generated by the particularities of the economies analyzed in our study. These results are consistent with the results obtained by Georgantopoulos and Filos [20]. In the study performed in 2017, they investigate the impact of corporate governance attributes on Greek banks during the crisis period and the authors find out, from the econometric calculations, that the chairman-chief executive officer duality influences positively for two out of four proxies the performance of the banks under study.

Although there are studies that challenge this governance model, given the implications of concentrating the power in the hands of a single person, we argue that this model can lead to a rise in the ROA in the light of the economic entities' increased focus on strategic investment projects. But these strategic decisions require a thorough knowledge of the business model, especially in the case of international investments. Given the informational asymmetry between the executive and the non-executive members of the board of directors, it is preferable for the chairman of this committee to have consistent and relevant information on the complexity of the operations undertaken by the economic entities.

We note that these regression coefficients are statistically significant in all models, including the ones controlling for industry effects or stock market effects. However, we observe that the particularities of the industries taken into consideration in the analysis generate a decrease in the marginal effect of the option for the dual model of corporate governance, the regression coefficient decreasing from 0.022 , in the case of omitting the fixed effects to a coefficient of 0.019 that controls for fixed effects. On the other side, stock markets' particularities generate an increase of the marginal effect of CEO duality on ROA, exceeding the value of 0.023 determined in case of the model that controls for firms' characteristics and omits the fixed effects influence. On those circumstances, the higher influence of national regulation of exchange securities is reflected, compared with the impact of industry guidelines related to corporate governance.

The diversity within the board of directors proves to be beneficial at the ROA level, given that the value of the regression coefficient is positive in all models depicted in Table 4. Therefore, regardless of 
the specifics of stock markets or of the particularities of the industry, the diversity within the board of directors can represent a management decision that may lead to an increase in the ROA.

These results reveal the efforts made at a regional and national level to promote the role of women in the management structures of economic entities. These results are in line with the results obtained by Erhardt et al. [60] and Carter et al. [39] which are limited to the analysis of entity samples operating in the US economy. At the same time, studies such as that of Bart et al. [61] emphasize that women are more efficient than men at the board level. Wang [38] also depicted that the presence of women in the board affects a firm's operating results because women directors are more sensitive to risk and they serve a strong supervisory function.

However, we can observe that the coefficient of 0.008 related to the model controlling for industry fixed effects is higher than the coefficient of 0.003 related to the model controlling for stock market fixed effects. On those circumstances, we conclude that the practice related to board composition and proportion of women to be included as board members reside more from industry guidelines than from national regulation, with smaller influence generated by company size, stock market value or no significant influence determined by the stock exchange securities regulation.

Similar to the implications of the board of director's size, the number of non-executive members proves to be statistically insignificant in terms of the marginal effect on the ROA, given that the significance level with which the regression coefficient is confirmed to be significantly different from 0 exceeds the minimum accepted significance level. These results are similar to the studies of De Andres et al. [62], which could not validate a statistically significant relationship between the number of non-executive members and the ROA level.

From the results summarized in Table 4, corresponding to the estimated models (1)-(3), we notice that, given the range of the marginal effect generated at the ROA level, the determinant factors are the dichotomous variables describing the existence of an audit committee and the favorable/modified opinion expressed by the external auditor on the certification of the financial statements of the economic entities. Existence of an audit committee and the favorable opinion of the external auditor on the certification of the financial statements prove to be extremely important in industries such as construction, finance, or logistics. Moreover, those two variables generate under Caeteris Paribus conditions, the highest marginal effect on ROA, compared with the marginal effect generated by the other variables considered in the regression models, no matter fixed effects are considered or not.

The existence of an audit committee represents a condition to guarantee the reliability of the financial-accounting information, "offering credibility to the information needed in the decisional process" [63], implicitly of the information underlying the calculation of the ROA. In order to increase corporate governance quality, the 8th EU Company Law Directive enacted a mandatory audit committee in publicly listed companies in the EU and defined its tasks and responsibilities [64]. The results obtained show that the existence of an audit committee is a favorable premise of a satisfactory ROA level, results in line with the ones obtained by Laing and Weir [44]. We notice that, regardless of the specifics of the national economy or of the particularities of the industries, the regression coefficient corresponding to the Audit Committee variable is positive, in case of all models from (1) to (5), with a significance level of $5 \%$. For the model controlling the fixed effects generated by the particularities of the industry, the marginal effect of the Audit Committee variable cancels the negative marginal effect of the Board size variable. Under these circumstances, we may appreciate that the decisions taken within the board of directors are facilitated by the quality of the information provided by the executive management to the members of the board. This quality is guaranteed by the existence of the audit committee [65]. A similar interpretation could be the one regarding the implications of ensuring the quality of the financial statements among non-executive members, through the existence of an audit committee. We cannot state, however, to what extent the mechanisms and tools used by the audit committee are effective in terms of the quality of the financial statements, the degree of compliance at the level of the economic entity, or the effectiveness of the decision-making processes and structures. 
The econometric results regarding the implications of the audit opinion on the ROA are similar. Thus, a favorable opinion on the quality of the financial statements translates into a positive marginal effect of the Audit Opinion variable on the ROA, regardless of the fixed effects generated by the specifics of the national economy, or by the particularities of the industry the economic entity operates in.

What we should notice is the increase of the regression coefficient from 0.037 to 0.051 , in the case of the analysis of the fixed effect generated by the industry. These results are closely related to the investors' and other stakeholders' perception on the quality of information released by managers through corporate reporting. Thus, certain industries are characterized by a lower aversion to uncertainty, which is why investors react positively, but in a different way if there is an audit committee that operates effectively at the level of the economic entity. This statement is also supported by the fact that these governance mechanisms ensure a more efficient management of the risks specific to the business model.

Overall, we notice that both models (1) and (3), which analyze the fixed effect generated by the specifics of the industries, and model (4), which analyzes the fixed effect generated by the particularities of the stock markets, seem to be not representative. Given the low adjusted coefficient of determination, ranging between $5 \%$ and $11 \%$, the models do not provide sufficient clues as to the implications of corporate governance mechanisms on the ROA level. In this regard, we aim to analyze the implications of these mechanisms on economic performance, controlling the model according to a series of variables that are relevant for outlining economic particularities of entities included in our sample. Consequently, we believe that the analysis of the implications of corporate governance mechanisms on the entities' economic performance provides information on the isolated effects of the business model. To this purpose, we proceeded to estimating econometric models, by controlling the effect of the capitalization level of the economic entities, the size of the economic activity, and the debt level. If the size of the economic activity provides hints as to the complexity of the business model, the debt level of the economic entities represents a complementary control performed by the credit institutions on the opportunity and profitability of the economic operations. Finally, yet importantly, we believe that the level of the stock market capitalization is relevant in the context of this study, especially according to the hypothesis that capital markets ensure an improvement of the optimal-useful allocation of investment funds of economic entities.

In Table 4, we notice that the control variables introduced in the econometric model are significantly different from 0 , being statistically validated with a significance level below $5 \%$. The marginal effect of these variables at the ROA level is relatively stable, keeping the constant sign at the level of the regression coefficients, both for the model controlling the impact of the fixed effects generated by the industry and for the model controlling the impact of the fixed effects generated by the specifics of the national economy.

On the one hand, we notice there is no significant negative effect generated by the level of the financial leverage on the ROA, in spite of the fact that an increased debt level implies an increase in borrowing costs, with direct implications at the level of the accounting result.

On the other hand, we notice that the size of the economic activity, reflected by the value of the assets engaged directly in the company's operations, determines an increase in the ROA. Given the financial resources available for investments that a highly developed company has, the financing potential of profitable investment projects, even in the medium and long term, is much better exploited as opposed to those less developed companies that have to resort to other, more expensive, financing options. At the same time, more developed companies tend to focus their development strategies on allocating funds to business models that seek vertical and horizontal integration, strengthening control over the entire value chain. Under these circumstances, the company benefits from differentiated remuneration conditions of the human factor, from a differentiated potential for selling products, etc. So, either the cost price is reduced, or the revenues are high, with implications on the company's profitability. However, this marginal effect of the complexity of the business model is exploited as 
long as the marginal administration costs are lower than the marginal revenues obtained from the expansion/diversification of the economic operations.

Last but not least, we notice that the level of capitalization of companies generates a positive marginal effect at the ROA level. This result attests to the fact that investors' interest is higher in an economic entity that increases its financing solutions, at lower costs than those obtained by contracting bank loans.

The results corresponding to the variables describing the corporate governance mechanisms are summarized in Table 4, within models (2) and (5). We could not have estimated a fixed-effects regression model on stock markets clustering as well, because the number of industry/stock market clusters is lower than the number of regression parameters to be estimated.

At first sight, we notice that the sign of the regression coefficients is maintained if we include the control variables involved in the study; either we talk about COE duality, women in board, audit committee, or auditor opinion variables. Regression coefficients remain positive, regardless of the fixed effects considered in the analysis.

Our results are in line with the ones obtained by Chau and Grey [66], Chan and Li [67], Hussain et al. [68], and Dahya and McConnell [26], which argue that a board of directors consisting of independent members leads to an improvement in the entities' economic performance. However, the positive implications of monitoring the company's activity by independent members on the board of directors are statistically significant only if we consider fixed effects generated by the specific of stock markets. As shown in Figure 2, companies listed in FTSE or IBEX prefer to comply with the governance principle of independence of the board of directors, compared with companies listed on WIG or BSE market. The practice in this area seem to be somehow related to the maturity of the capital markets, as FTSE and IBEX are highly capitalized markets, while BSE or WIG markets have just recently promoted to emerging markets. The fixed effect generated by the profile of stock markets can be explained by securities regulation, which are much more oriented towards investors' protection, which mandate for independence of the board of directors. The presence of independent directors is an important corporate governance mechanism that can lead to a better supervision of board effectiveness [69]. Otherwise, as long as the board of directors consists in a significant number of executive members compared to the number of non-executive members, the independent members on the board of directors could come into conflict with the executive directors, who are also members on the board of directors, with profound consequences in terms of the speed of the decision-making process.

The results summarized in Table 4 confirm the hypothesis that the size of the board of directors is a determining factor in reducing the level of the ROA. These results are consistent with the studies of Nguyen et al. [70], De Andres et al. [62], or Guest [71]. These results show once again that, on a large board, it is often difficult to reach a consensus on the decisions to be taken. However, it should be noticed that the marginal effect is lower in the analysis of the fixed effects generated by the specifics of the industry. These results are statistically significant both for the general econometric model (model (2)) and for the econometric model that takes into account the fixed effects generated by the particularities of the industry the economic entities operate in (model (3)). Thus, the effect of the board size is significantly different from 0 . However, companies should weigh very well their decisions regarding the board size, precisely in order to reduce the negative effect on the profitability of economic entities. However, it seems that the board size is not affecting statistically significant ROA, once control variables are considered, as the voice of capital markets and the business model seem to be factors that are more important.

The other variables regarding corporate governance, introduced in the econometric model, are statistically insignificant, given that the corresponding significance level exceeds the maximum allowed level of $10 \%$.

Tables 5 and 6 summarizes statistics resulted from running additional tests aimed to help us on deciding if industry or specific characteristics of stock markets related to corporate governance mechanisms generate significant influence on firms' financial performance. 
Table 5. Hausman test-based on industry panels—ROA.

\begin{tabular}{ccccc}
\hline Statistic & Chi-Sq. Statistic & d.f. & Prob. & \\
\hline relative to industry factor & 17.097917 & 6 & 0.0089 & \\
\hline Variable & Fixed & Random & Var(Diff.) & Prob. \\
Board size & -0.004091 & -0.004572 & 0 & 0.2285 \\
Non executives members & -0.000362 & 0.000128 & 0.000001 & 0.498 \\
CEO duality & 0.018628 & 0.021708 & 0.000002 & 0.0377 \\
Women in Board & 0.007537 & 0.006585 & 0 & 0.1529 \\
Audit Committee & 0.044594 & 0.035803 & 0.000016 & 0.0277 \\
Audit opinion & 0.051296 & 0.037106 & 0.000036 & 0.0177 \\
\hline
\end{tabular}

Table 6. Lagrange Multiplier for random effects tests-based on sector panels-ROA.

\begin{tabular}{ccccc}
\hline Model & \multicolumn{2}{c}{ without Control Variables } & \multicolumn{2}{c}{ with Control Variables } \\
\hline Test & Stat & Sig. & Stat & Sig. \\
\hline Breusch-Pagan & 0.001704 & 0.9671 & 0.384724 & 0.5351 \\
Honda & 0.041285 & 0.4835 & -0.620261 & - \\
King-Wu & 0.041285 & 0.4835 & -0.620261 & - \\
Standardized Honda & 1.236281 & 0.1082 & -0.620261 & 0.4007 \\
Standardized King-Wu & 1.236281 & 0.1082 & -0.620261 & 0.4007 \\
\hline${ }^{*}$ Mixed chi-square asymptotic critical values: & & \\
\hline $1 \%$ & 7.289 & & \\
$5 \%$ & 4.321 & & \\
$10 \%$ & 2.952 & & \\
\hline
\end{tabular}

* It is standard format provided by statistical software application. Critical values are necessary to compare Stat with them, so we can confirm or not null hypothesis.

Based on significance level (Sig. $=0.0089<1 \%$ ), Table 5 results show that the fixed effects models (models (3) and (5)) are more efficient than the fixed effects model (model (2)), leading to the conclusion that there are significant fixed effects generated by the industry characteristics. Consequently, those results underline the fact that can be confirmed that there exists an industry-based pattern related to how corporate governance mechanism are defined and implemented in practice. For instance, in Figure 6, we can observe that firms operating in industrial activities generated the highest fixed effects on ROA, being a good benchmark for the other companies as well in terms of best practice when designing and implementing different tools of corporate governance. Together with firms operating providing services, like banking, insurance, or management consultancy, these firms have designed more corporate governance systems that serve to complex business model having a high incidence of international operations and significant risk of regional economic uncertainty. On the other side, firms operating in logistics and transportation are described by less complex business models, with a higher weight of automated processes along the operations, supported by higher standardized operational processes. All of these are the recipe of more effective corporate governance processes, supported by audit proof tools.

This way, it seems there is a widespread in practice within firms operating on different areas of activity, as a consequence of a more flexible national regulation on the area of legal requirements related to corporate governance. On those circumstances, industry guidelines synthesizing best practices in corporate governance become an important tool and standard of evaluating corporate governance systems and controls effectiveness. However, as long as those guidelines are not mandatory, voluntary implementation is expected to be affected by firm-specific considerations, generally related to managers' perspective on the role of corporate governance tools and mechanisms. 
Table 6 summarizes statistics resulted from running a LM test for random effects generated at stock markets level, relevant to analyze if pooled OLS regression model (model (1)) is more efficient than an alternative random effects model.

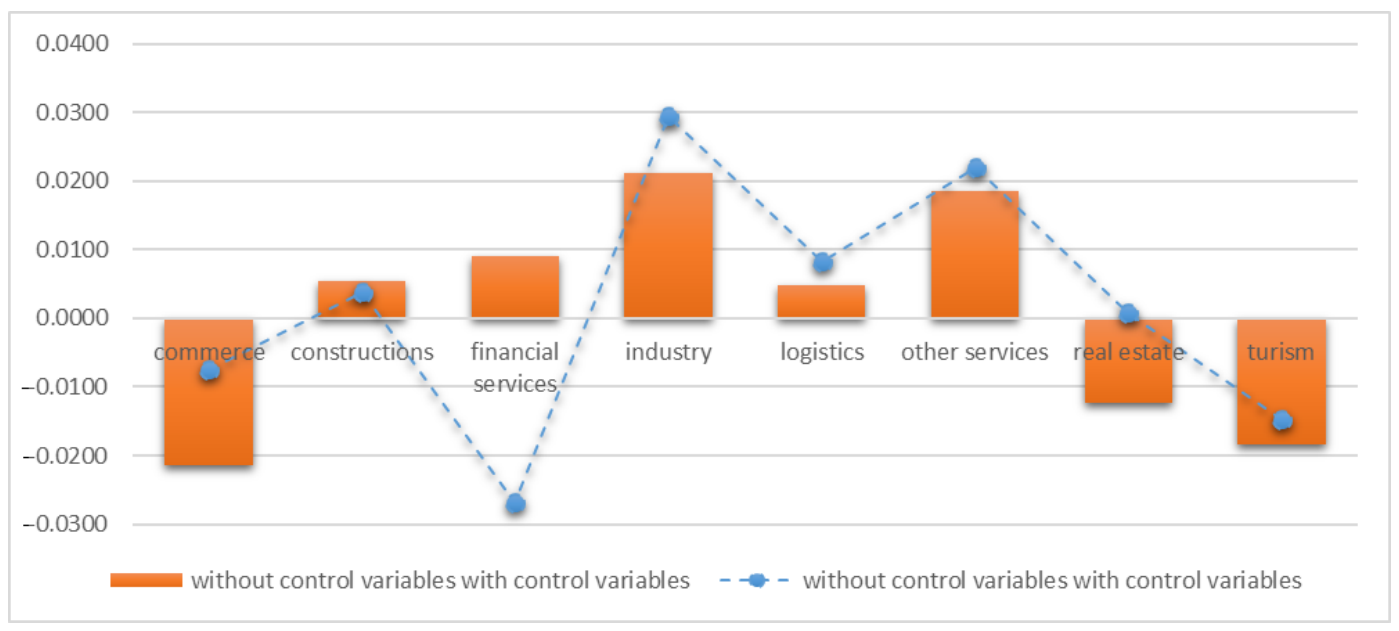

Figure 6. Fixed effects generated by industry profile on ROA.

Based on results obtained, we reject the impact of the profiles of stock markets considered in our analysis, as there is no significant variation on the variables considered in the model generated by the stock markets characteristics. For any of the tests performed, the Stat obtained is lower than the mixed chi-square asymptotic critical value corresponding to a significance level of $10 \%$, meaning that the null hypothesis cannot be rejected and that the pooled OLS model is more efficient than the random effects model. Moreover, in the case of the Breusch-Pagan test, the probability of 0.9671 is higher than the acceptable significance level of $10 \%$. Those results just confirm there are no significant differences across firms listed on the same stock market. These results could be justified by the definition of minimum corporate governance requirements through corporate governance codes defined and implemented on each stock market level. Moreover, stock markets like BSE or FTSE ask listed companies to disclose the compliance on each of the main requirements derived from those codes, which lead to an additional pressure on managers to follow best practices on corporate governance. Otherwise, as stated by agency theory, companies' financing policies will be affected.

In spite of missing fixed effects or random effects generated by stock markets, the variance of the intercept obtained from a multiple ANOVA analysis is 0 , which coincides with the conditions of random effects generated on ROA, by firms' characteristics. In addition, we observe there is a significant interaction between industry profile and stock markets profile, as Sig Industry $*$ Stock market $=0.073<10 \%$. Consequently, we emphasize that fixed effects generated by industry specific profiles are facilitated somehow by the maturity of stock markets as well.

Overall, the results from Table 7 underlined the fact that there is no pattern drawn up on a stock market level that could describe a relative uniformity on corporate governance practice, leading to no significant influence of corporate governance mechanism on financial performance. Eventually, the influence on financial influence of corporate governance mechanism translates as long as related processes prove to be effective. On those circumstances, additional variables to control for effectiveness of corporate governance mechanisms are useful. However, the ground of our analysis resumes more to the corporate governance framework, than the effectiveness of internal firms' corporate governance related processes, like the effectiveness of the internal control system, the level of compliance to legal regulation and internal policies, or the efficiency of the risk management system. 
Table 7. Tests of Between-Subjects Effects-ROA.

\begin{tabular}{ccccccc}
\hline Source & Type III Sum of Squares & df & Mean Square & F & Sig. & Partial Eta Squared \\
\hline Corrected & $0.156^{\mathrm{a}}$ & 35 & 0.004 & 1.730 & 0.011 & 0.242 \\
Model & 0.436 & 1 & 0.436 & 168.6 & 0.000 & 0.470 \\
Intercept & 0.027 & 7 & 0.004 & 1.490 & 0.173 & 0.052 \\
Industry & 0.008 & 4 & 0.002 & 0.786 & 0.536 & 0.016 \\
Stock market & 0.093 & 24 & 0.004 & 1.493 & 0.073 & 0.159 \\
Industry * & 0.491 & 190 & 0.003 & & & \\
Stock market & 1.580 & 226 & & & & \\
Error & 0.648 & 225 & & & & \\
Total & & & & & \\
Corrected & & & & \\
Total & & &
\end{tabular}

$\mathrm{R}$ Squared $=0.242$ (Adjusted R Squared $=0.102$ ); Computed using alpha $=0.05 .{ }^{*}$ It is standard formulation on statistical analysis, it is the interaction effect of Industry and Stock market at once, on our dependent variable ROA. The " $a, b$ " is a remark on overall table, showing significance level considered for the analysis.

Nonetheless, we observe that models (2) and (5) are statistically significant, given that the significance level for the $F$-test is $0 \%$, which indicates a significant influence of certain corporate governance mechanisms, amplified by the individual particularities of the economic entities included in the analyzed sample. The $R^{2}$ are better in case of models controlling for firms' characteristics, increasing from $5.31 \%$ to $32.81 \%$ in the case of model (2), or from $10.08 \%$ to $35.49 \%$ in the case of model (5). Therefore, firms' individual policies seem to represent a significant factor of differentiation on financial performance. Corporate governance mechanisms are relevant factors as well, like the audit committee, the CEO duality model, the board size, the auditor opinion, or the board diversity. In spite of those results, those corporate governance mechanisms are subordinated to firms' economic drivers, like the business model and market value. For instance, board size of the board of directors depend on the complexity of the business model. On the other hand, highly capitalized firms are continuously monitored and followed by financial analysts that increase the pressure on managers to disclose financial information of high quality, as analysts' forecasts already draw-up investors' expectations and create the premises for future potential litigation costs for managers.

\subsection{The Influence of Corporate Governance Mechanism on Performance Measured through the ROE Indicator}

Given the unrepresentative role of corporate governance mechanisms at the level of the return on assets engaged in the operations of economic entities, illustrated in the previous sections of this research, we want to investigate if the financial rates are differently influenced by these mechanisms. In this sense, we proceeded to analyze the implications of corporate governance mechanisms at the level of the return on equity, namely ROE. Thus, we aim to analyze the impact of the corporate governance structures and mechanisms of paying the residual interest of shareholders. This financial rate reflects much better the implications of the financing structure of the economic entities, given that there is a clear delimitation between the various financing sources.

The results of this analysis are summarized in Table 8. Overall, compared to similar results presented in Table 4, we notice that the sign of the regression coefficients is maintained when passing from the analysis of the implications of corporate governance on the $R O A$ to the analysis of the same implications, but this time on the $R O E$ indicator.

At the same time, we find that the marginal effect generated at the ROE level by corporate governance mechanisms is amplified, in the case of CEO duality, women on board of directors, audit committee, and auditor opinion.

We equally notice that in the case of econometric models that do not include control variables, we obtain regression coefficients significantly different from 0 from a statistical point of view, with a significance level below $10 \%$. It is the case of the Women on board variable, the Audit Committee variable, or the Audit Opinion variable, as they are represented in models (7), (8), and (9).

The boards of directors' option to grant the quality of president to the company's CEO proves to be beneficial at the ROE level. The transition from ROA model to ROE model shows a decrease of 
regression coefficients related to $\mathrm{CEO}$ duality, expect for the models that control for firms' characteristics as well. In spite of those results, CEO duality does not significantly affect ROE. Such a situation could be justified by a different weight of CEO given to ROA and ROE. If ROA is of much more interest from an operation processes effectiveness point of view, ROE rather captures investors' interest. Once the chairman of the board of directors is the same with firm's CEO, strategic decisions decided are to be oriented more on operational processes and their effectiveness.

Table 8. The econometric analysis of corporate governance mechanisms on the ROE.

\begin{tabular}{|c|c|c|c|c|c|}
\hline \multicolumn{6}{|c|}{ Dependent Variable } \\
\hline \multicolumn{6}{|c|}{ ROE } \\
\hline & \multicolumn{5}{|c|}{ Models } \\
\hline Determinant Variables & (6) & (7) & (8) & (9) & (10) \\
\hline Board size & $\begin{array}{l}-0.006 \\
(0.006)\end{array}$ & $\begin{array}{l}-0.001 \\
(0.006)\end{array}$ & $\begin{array}{l}-0.003 \\
(0.006)\end{array}$ & $\begin{array}{l}-0.006 \\
(0.003)\end{array}$ & $\begin{array}{c}0.002 \\
(0.006)\end{array}$ \\
\hline Non-executive members & $\begin{array}{l}-0.006 \\
(0.008)\end{array}$ & $\begin{array}{l}-0.010 \\
(0.007)\end{array}$ & $\begin{array}{l}-0.010 \\
(0.008)\end{array}$ & $\begin{array}{c}0.001 \\
(0.003)\end{array}$ & $\begin{array}{c}-0.015^{\text {** }} \\
(0.007)\end{array}$ \\
\hline CEO duality & $\begin{array}{c}0.014 \\
(0.029)\end{array}$ & $\begin{array}{c}0.024 \\
(0.027)\end{array}$ & $\begin{array}{c}0.010 \\
(0.029)\end{array}$ & $\begin{array}{c}0.025 \\
(0.011)\end{array}$ & $\begin{array}{c}0.025 \\
(0.027)\end{array}$ \\
\hline Women on Board & $\begin{array}{l}0.040 * \\
(0.008)\end{array}$ & $\begin{array}{l}0.034 * \\
(0.008)\end{array}$ & $\begin{array}{l}0.044 * \\
(0.008)\end{array}$ & $\begin{array}{c}0.003 \\
(0.003)\end{array}$ & $\begin{array}{c}0.038^{* *} \\
(0.008)\end{array}$ \\
\hline Audit Committee & $\begin{array}{c}0.093^{* * *} \\
(0.050)\end{array}$ & $\begin{array}{c}0.041 \\
(0.047)\end{array}$ & $\begin{array}{c}0.096^{* *} \\
(0.051)\end{array}$ & $\begin{array}{c}0.032 \\
(0.018)\end{array}$ & $\begin{array}{c}0.056 \\
(0.048) \\
\end{array}$ \\
\hline Audit Opinion & $\begin{array}{c}0.079 \\
(0.062)\end{array}$ & $\begin{array}{c}0.098^{* * *} \\
(0.057)\end{array}$ & $\begin{array}{c}0.107^{* * *} \\
(0.064)\end{array}$ & $\begin{array}{c}0.035 \\
(0.022)\end{array}$ & $\begin{array}{c}0.132 \text { ** } \\
(0.059)\end{array}$ \\
\hline Stock market value & - & $\begin{array}{l}0.053 * \\
(0.008)\end{array}$ & - & - & $\begin{array}{c}0.055 \text { * } \\
(0.01)\end{array}$ \\
\hline Size & - & $\begin{array}{c}-0.036 \text { * } \\
(0.006)\end{array}$ & - & - & $\begin{array}{c}-0.041 \text { * } \\
0.007\end{array}$ \\
\hline Leverage & - & $\begin{array}{l}0.0008 \\
(0.001)\end{array}$ & - & - & $\begin{array}{l}0.001 \\
(0.00)\end{array}$ \\
\hline Model Validation & & & & & \\
\hline Sample size & 226 & 226 & 226 & 226 & 226 \\
\hline Fixed effects-industry & $\mathrm{N}$ & $\mathrm{N}$ & $\mathrm{Y}$ & $\mathrm{N}$ & $\mathrm{Y}$ \\
\hline Fixed effects—stock market & $\mathrm{N}$ & $\mathrm{N}$ & $\mathrm{N}$ & Y & $\mathrm{N}$ \\
\hline $\mathrm{R}^{2}$ adjusted & $11.12 \%$ & $26.66 \%$ & $13.56 \%$ & $6.35 \%$ & $28.15 \%$ \\
\hline Durbin-Watson stat & 1.79 & 2.00 & 1.96 & 1.97 & 2.04 \\
\hline $\mathrm{F}$ & 5.69 & 10.09 & 3.71 & 2.52 & 6.51 \\
\hline$p$ & 0.0000 & 0.0000 & 0.0000 & 0.0068 & 0.0000 \\
\hline
\end{tabular}

Notes: Standard errors are in parentheses. * significant for $5 \%$ significance level; ${ }^{* *}$ significant for $10 \%$ significance level; ${ }^{* * *}$ significant for $10 \%$ significance level.

In addition, this conceptual difference is observable on the level of marginal effects of women on the board, audit committee, and auditor opinion that increases in case ROA is replaced with ROE in the regression model. Those variables generate a higher positive effect on ROE compared with the influence of CEO duality variable. Therefore, the existence of an audit committee generates at the ROE level an increased marginal effect from 0.036 to 0.093 , a statistically significant value with a significance percentage below $10 \%$, a result consistent with the study conducted by Crisan and Fulop [72], who stated that "the role of the audit committee in corporate governance is essential," with an important role in monitoring the effectiveness of the risk management system, the internal control, and the financial reporting [73]. At the same time, the auditor's opinion on the certification of 
financial statements determines a positive marginal impact on the ROE, which increases from 0.037 to 0.079 , a statistically significant value with a significance level below $10 \%$, but only in case of the model controlling for firms' characteristics influence on ROE. In addition, the premises for quality of financial statements seem to be different between different areas of activity we have included in our study, as the regression coefficient for both variables in case we consider industry fixed effect are higher than the effects reflected by general OLS models. After all, these variables reflect a guarantee of the quality of the annual report and of the information released by the company's management to investors and other stakeholders through various financial communication channels [74]. Consequently, the higher the residual interest in the company's capital, the more important the investors' confidence in the company's management becomes.

Tables 9 and 10 summarizes statistics resulted from running additional tests aimed to help us on deciding if industry or stock markets' specific characteristics related to corporate governance mechanisms generate significant influence on firms' financial performance. In case of ROE analysis, firms' financing policy is better described, a fact drawn up even by the higher levels of regression coefficients corresponding to control variables considered compared to the ones derived from regression models that study ROA's corporate governance drivers.

Table 9. Hausman test-based on industry panels-ROE.

\begin{tabular}{ccccc}
\hline Statistic & Chi-Sq. Statistic & d.f. & Prob. & \\
\hline Relative to industry factor & 6.275863 & 6 & 0.393 & \\
\hline Variable & Fixed & Random & Var(Diff.) & Prob. \\
\hline Board size & -0.003457 & -0.004986 & 0.000001 & 0.1063 \\
Non-executive members & -0.009577 & -0.006792 & 0.000003 & 0.0973 \\
CEO duality & 0.009953 & 0.011422 & 0.000011 & 0.6633 \\
Women on Board & 0.04384 & 0.041653 & 0.000002 & 0.1503 \\
Audit Committee & 0.096314 & 0.093352 & 0.000069 & 0.7214 \\
Audit opinion & 0.107383 & 0.086075 & 0.000199 & 0.131 \\
\hline
\end{tabular}

Table 10. Lagrange Multipler for random effects tests—based on industry panels—ROE.

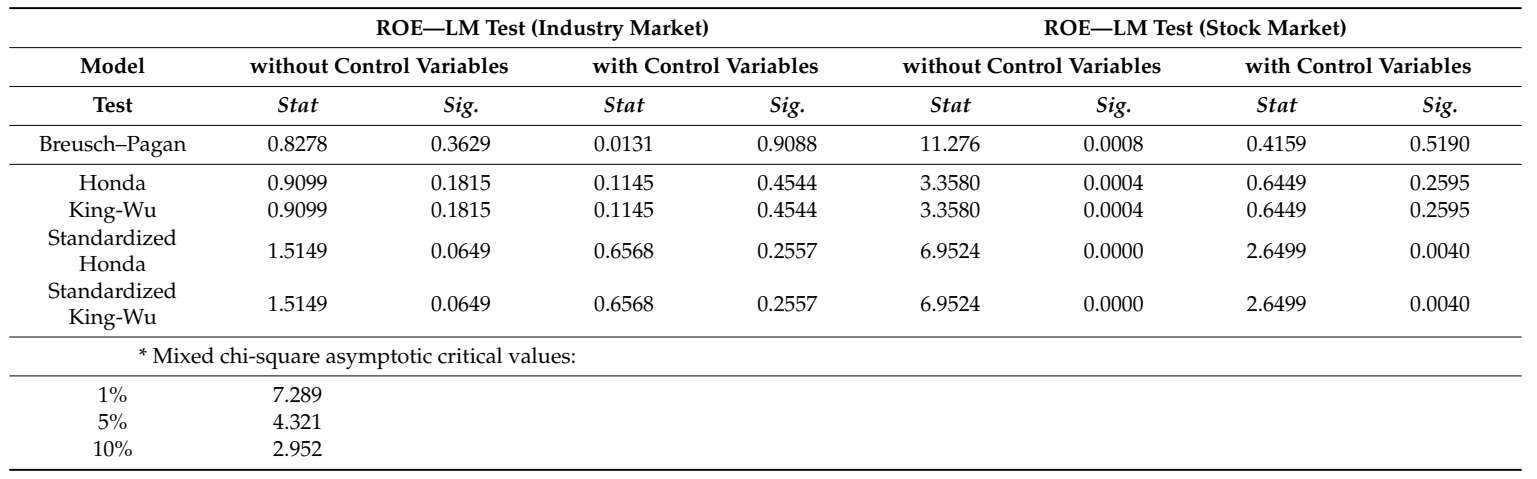

* It is standard format provided by statistical software application. Critical values are necessary to compare Stat with them, so we can confirm or not null hypothesis.

Based on significance level (Sig. $=0.393>10 \%$ ), the results from Table 9 show that the random effects model is more efficient than the fixed effects model (model (6)), leading to the conclusion that there is no fixed effects generated by the industry characteristics. However, the fixed-effects model is consistent [75], meaning that the coefficients provide relevant information related to marginal effects generated by industry.

The results for ROE random effects analysis underline the fact that there is no correlation between the industry dummy regressor and the other variables considered in the multiple regression. Consequently, those results underline the fact that it cannot be confirmed that there is an an 
industry-based pattern that exists that is related to how corporate governance mechanisms are defined and implemented in practice, no matter firms' financing policy. This way, it seems there is a wide spread in practice within firms operating in same area of activity, as consequence of a more flexible regulation on the area of legal requirements related to corporate governance.

Table 10 summarizes statistics resulted from running LM test for random effects, extremely relevant to analyze if pooled OLS regression model (model (6)) is more efficient than an alternative random effects model, in case of both effects generated by industry profile and stock market profile.

Our results reject the impact of panels considered in our analysis, as there is no significant variation on the variables considered in the model generated by the industry characteristics. For any of the tests performed, the Stat obtained is lower than the mixed chi-square asymptotic critical value corresponding to a significance level of $10 \%$. Moreover, in the case of the Breusch-Pagan test, the probability of 0.552 is higher than the acceptable significance level of $10 \%$. Those results just confirm there are no significant differences across areas of activity firm operate, or the stock market they are listed on. Even if there are industry-specific or stock-market specific guidelines related to how corporate governance mechanism should be defined and implemented, as long as they are not mandatory, the voluntary effect seem to be insignificant. In addition, it is useful to pay attention to what kind of key performance indicators those codes focus on.

Overall, as either, we include the control variables effect, or not, the results highlight there is no significant fixed or random effect generated by the industry. On those circumstances, we conclude there are additional factors that should be considered to better describe firm particularities when analyzing drivers of financial performance. Corporate governance mechanisms, company size, capital market voice, and financing policies are just part of the main drivers that can explain firms' financial performance. In spite of some mandatory controls in place related to the request of a uniform practice, in a framework characterized by a relatively high degree of institutionalization in the European Union area [76], like the Comply or Explain form incorporate in the Romanian annual report, the guidance on a country level related to best practice in corporate governance seems to be insufficient in order to be in line with the project of Europe 2020 agenda that provides three formulas of economic growth in Europe: intelligent, durable, and inclusive [77], although sustainability has become a national and international concern, ingrained in many organizational processes [78].

As the number of stock markets included in our analysis is lower than the parameters to be estimated on the regression models, we could not have run the Hausman test to assess if there are fixed effects that have to be considered to analyze the influence of stock markets profile on ROE.

However, running a multivariate ANOVA analysis, we observe in Table 11 that stock market profile generates significant differences on ROE disclosed by firms listed on different stock markets, with an $F$ test statistic of 5.918 for a significance level lower than $1 \%$. Contrary with the results disclosed on Table 7 for ROA, in the case of ROE, we find there is no significant interaction between the industry profile and stock market profile, as related significance level Sig $_{\text {Industry*Stock market }}=0.564>10 \%$.

Models (6)-(10) can be statistically validated, since the significance level corresponding to the $F$-test does not exceed the maximum allowed level of $1 \%$. At the same time, we notice an extremely low adjusted coefficient of determination; therefore, we conclude that the isolated effect of corporate governance mechanisms does not sufficiently explain the ROE level. But these results only illustrate the secondary marginal effect of corporate governance mechanisms on the ROE, as the adjusted coefficient of determination increases significantly from the range of $6.35-13.56 \%$ corresponding to models (6), (8), and (9), to the range $16.66-28.51 \%$ related to models (7) and (10). 
Table 11. Tests of Between-Subjects Effects-ROE.

\begin{tabular}{ccccccc}
\hline Source & Type III Sum of Squares & df & Mean Square & F & Sig. & Partial Eta Squared \\
\hline Corrected Model & 1.499 a & 35 & 0.043 & 2.068 & 0.001 & 0.276 \\
Intercept & 2.206 & 1 & 2.206 & 106.506 & 0.000 & 0.359 \\
Industry & 0.058 & 7 & 0.008 & 0.401 & 0.901 & 0.015 \\
Stock market & 0.490 & 4 & 0.123 & 5.918 & 0.000 & 0.111 \\
Industry * Stock market & 0.461 & 24 & 0.019 & 0.928 & 0.564 & 0.105 \\
Error & 3.935 & 190 & 0.021 & & & \\
Total & 11.102 & 226 & & & & \\
Corrected Total & 5.434 & 225 & & & & \\
\hline
\end{tabular}

a. $\mathrm{R}$ Squared $=0.276$ (Adjusted $\mathrm{R}$ Squared $=0.142$ ); $\mathrm{b}$. Computed using alpha $=0.05 .{ }^{*}$ It is standard formulation on statistical analysis, it is the interaction effect of Industry and Stock market at once, on our dependent variable ROA.

The " $a, b$ " is a remark on overall table, showing significance level considered for the analysis.

\section{Conclusions}

Is corporate governance a prerequisite for increasing the performance and achieving sustainable development of the listed entities? The answer to this question is a topic of great interest in literature, being debated by many researchers in the field, due to the importance of this concept nowadays.

Our study examined the relationship between corporate governance attributes and financial performance measured by the Return on Assets (ROA) and Return on Equity (ROE) indicators, given the information published by 226 entities listed on five stock exchanges from Europe, namely the main market from Bucharest Stock Exchange (BSE) in Romania, the ATHEX main market in Greece, FTSE 100 from Great Britain, IBEX 35 from Spain, and WIG 20 from Poland for the period 2016-2018. By using cross-country investigation, we covered important industries, enhancing the generalizability of our results. The econometric models and tests performed revealed that CEO duality, the number of non-executive directors, the number of women on board, audit committee, and external auditor's opinion influenced performance. CEO duality can increase the performance of companies, as there is only one person able to take efficient and timely decisions. According to the agency theory, a higher percentage held by non-executive directors leads to an increase in the entity's performance, and the results of our study can confirm this hypothesis. Our study also reflects the fact that the variable represented by the number of women on board is positive and statistically significant because different perspectives and ideas may occur due to the existence of gender diversity within the board that can improve performance. The role of the Audit Committee is to improve the quality of information disclosed by financial statements, which is extremely useful for shareholders and management as well, especially in the area of financial reporting. Thus, the role of the audit committee is to reduce the information asymmetry, being particularly important within the entity, especially in the prevention of financial-accounting frauds that have led over the years to bankruptcy of a number of prestigious companies. External auditors' opinion, guaranteeing the quality of financial statements, in all material aspects, strengthens the confidence in the management team and reflects credibility and transparency, essential characteristics for the sustainable and efficient development of any economic entity.

Our results also underlined the fact that an industry-based pattern related to how corporate governance mechanism are defined and implemented in practice exists, for financial performance measured through ROA indicator. Because some of the models estimated in our study were not representative, given the low adjusted coefficient of determination, we deemed it appropriate to introduce in future studies, the impact of government regulatory mechanisms for corporate governance practices. A more in-depth analysis of the combined effect of corporate governance mechanisms would also equally involve an analysis of the impact of the legislative framework on corporate governance and the effectiveness of monitoring and control mechanisms of government institutions and relevant bodies and associations.

Nevertheless, our research has limitations. Our regression models relied on financial and non-financial information collected manually from the Annual and Sustainability reports and the inclusion in the sample, in the case of Greece, Poland, and Spain, only those companies that published their reports in English. Thus, future research directions may target larger data series in terms of 
the number of years under investigation, as well as other performance measurement indicators and methods of data collection.

Despite this limitation, our study contributes to the literature in three perspectives. The first one refers to the fact that it studies the relationship between corporate governance and performance in order to achieve sustainable development, taking into account five important stock markets from Europe. The second one refers to the analysis performed in order to determine the existence of an industry-based pattern related to how corporate governance mechanism are defined and implemented in practice. There is also an econometrical model for the evaluation of the influence of corporate governance mechanisms on performance that may become very useful for those companies that intend to develop a sustainable business.

Author Contributions: Conceptualization, O.-C.B., D.M., A.-C.D., O.B., and V.B.; methodology, O.B. and V.B.; software, V.B.; validation, V.B.; formal analysis, V.B.; investigation, O.B., V.B., and A.-C.D.; resources, O.B. and V.B.; data curation, O.B. and V.B.; writing-original draft preparation, O.-C.B., D.M., A.-C.D., O.B., and V.B.; writing-review and editing, O.-C.B., D.M., A.-C.D., O.B., and V.B.; visualization, O.-C.B., D.M., and A.-C.D.; supervision, O.-C.B., D.M., A.-C.D.; project administration, O.-C.B., D.M., A.-C.D., O.B., and V.B. All authors have read and agreed to the published version of the manuscript.

Funding: This research received no external funding.

Conflicts of Interest: The authors declare no conflict of interest.

\section{References}

1. Zheng, C.; Kouwenberg, R. A bibliometric Review of Global Research on Corporate Governance and Board Attributes. Sustainability 2019, 11, 3428. [CrossRef]

2. Paniagua, J.; Rivelles, R.; Sapena, H. Corporate governance and financial performance: The role of ownership and board structure. J. Bus. Res. 2018, 89, 229-234. [CrossRef]

3. Shahid, M.S.; Abbas, M. Does corporate governance play any role in investor confidence, corporate investment decision relationship? Evidence from Pakistan and India. J. Econ. Bus. 2019, 105. [CrossRef]

4. Pillai, R.; Al-Malkawi, H.-A.N. On the relationship between corporate governance and firm performance: Evidence from GCC countries. Res. Int. Bus. Fin. 2018, 44, 394-410. [CrossRef]

5. Kim, J.M.; Jun, C.; Han, H. Sustainable causal interpretation with Board Characteristics: Caveat Emptor. Sustainability 2020, 12, 3429. [CrossRef]

6. Siminica, M.; Cristea, M.; Sichigea, M.; Noja, G.; Anghel, I. Well-Governed Sustainability and Financial performance: A new integrative approach. Sustainability 2019, 11, 4562. [CrossRef]

7. Wall Street-Bucharest Stock Exchange, the Highest Increase in the World in 2019-Complete Ranking. Available online: https://www.wall-street.ro/articol/Piete-de-capital/248437/bursa-de-valori-bucuresti-cea-mai-marecrestere-din-lume-in-2019-cum-arata-clasamentul-complet.html\#gref (accessed on 20 May 2020).

8. El-Kassar, A.N.; El-Gammal, W.; Fahed-Sreih, J. Engagement of family members, corporate governance and social responsibility in family-owned entreprises. J. Organ. Chang. Manag. 2018, 31, 215-229. [CrossRef]

9. Kuang-Hua, H.; Sin-Jin, L.; Ming-Fu, H. A fusion approach for exploring the key factors of corporate governance on corporate social responsibility performance. Sustainability 2018, 10, 1582. [CrossRef]

10. Zhang, Q.; Loh, L.; Wu, W. How do Environmental, Social and Governance Initiatives Affect Innovative Performance for Corporate Sustainability? Sustainability 2020, 12, 3380. [CrossRef]

11. Al-ahdal, W.; Alsamhi, M.; Tabash, M.; Farhan, N. The impact of corporate governance on financial performance of Indian and GCC listed firms: An empirical investigation. Res. Int. Bus. Financ. 2020, 51. [CrossRef]

12. Zabri, M.S.; Ahmad, K.; Wah, K.K. Corporate Governance Practices and Firm Performance: Evidence from Top 100 Public Listed Companies in Malaysia. Proc. Econ. Financ. 2016, 35, 287-296. [CrossRef]

13. Yameen, M.; Farhan, N.; Tabash, M. The impact of corporate governance practices in firm's performance: An empirical evidence from Indian tourism sector. J. Int. Stud. 2019, 12, 208-228. [CrossRef] [PubMed]

14. Mak, Y.T.; Roush, M.L. Factors Affecting the Characteristics of Boards of Directors: An Empirical Study of New Zealand Initial Public Offering Firms. J. Bus. Res. 2000, 47, 147-159. [CrossRef] 
15. Certo, S.T. Influencing initial public offering investors with prestige: Signaling with board structures. Acad. Manag. Rev. 2003, 28, 432-446. [CrossRef]

16. Hu, M.; Loh, L. Board Governance and Sustainability disclosure: A cross-Sectional Study of Singapore -Listed Companies. Sustainability 2018, 10, 2578. [CrossRef]

17. Bae, S.M.; Masud, A.K.; Kim, J.D. A cross-country investigation of corporate governance and corporate sustainability disclosure: A signaling theory perspective. Sustainability 2018, 10, 2611. [CrossRef]

18. Fernandez-Gago, R.; Cabeza-Garcia, L.; Nieto, M. Independent directors' background and CSR disclosure. Corp. Soc. Respon. Environ. Manag. 2018, 25. [CrossRef]

19. Hoti, A.H.; Dermaku, A. Corporate governance in the banking industry of Kosovo: Does board size and board independence matter? J. Finan Bank. Stud. 2018, 7, 20-34. [CrossRef]

20. Georgantopoulos, A.; Filos, J. Corporate governance mechanism and bank performance. Evidence from the greek banks during crisis period. Invest. Manag. Financ. Innov. 2017, 14, 160-172. [CrossRef]

21. Zhou, H.; Owusu-Ansah, S.; Maggina, A. Board of directors, audit committee, and firm performance: Evidence from Greece. J. Int. Account. Audit. Tax. 2018, 31, 20-36. [CrossRef]

22. Adams, R.B.; Mehran, H. Bank board structure and performance: Evidence for large bank holding companies. J. Financ. Intermed. 2012, 21, 243-267. [CrossRef]

23. Franken, J.R.V.; Cook, M.L. Do corporate governance recommendations apply to US agricultural cooperatives? Sustainability 2019, 11, 5321. [CrossRef]

24. Felicio, A.; Ivashkovskaya, I.; Rodriguez, R.; Stepanova, A. Corporate governance and performance in the largest European listed banks during the financial crisis. Innovar 2014, 24, 83-98. [CrossRef]

25. Garefalakis, A.; Dimitras, A.; Lemonakis, C. The effect of Corporate Governance Information (CGI) on banks' reporting performance. Invest. Manag. Financ. Innov. 2017, 14, 63-70. [CrossRef]

26. Dahya, J.; McConnell, J. Board composition, corporate performance and the Cadbury committee recommendation. J. Financ. Quantit. Anal. 2007, 42, 535-564. [CrossRef]

27. Boitan, I.; Nitescu, D. Does Corporate Governance Support Efficiency in Banking Business? Evidence from European Systemic Banks. Ekon. Časopis 2019, 67, 525-549.

28. Cornett, M.M.; Marcus, A.J.; Tehranian, H. Corporate governance and pay-for-performance: The impact of earnings management. J. Financ. Econ. 2008, 87. [CrossRef]

29. Coles, J.L.; Daniel, N.D.; Naveen, L. Boards: Does one size fit all? J. Financ. Econ. 2008, 87. [CrossRef]

30. Kiel, G.C.; Nicholson, G. Board composition and corporate performance: How the Australian experience informs contrasting theories of corporate governance. Corp. Gov. Int. Rev. 2003, 11. [CrossRef]

31. Nazar, M.C.A. Does CEO duality affect firms performance? Evidence from Sri Lanka. Intern. J. Adv. Manag. Econ. 2016, 5, 56-60.

32. Grose, C.; Kargidis, T.; Chouliaras, V. Corporate governance in practice. The Greek case. Proc. Econ. Financ. 2014, 9, 369-379. [CrossRef]

33. Naciti, V. Corporate Governance and board of directors. The effect of a board composition on firm sustainability performance. J. Clean. Prod. 2019, 237. [CrossRef]

34. Elsayed, K. Board size and corporate performance: The missing role of board leadership structure. J. Manag. Gov. 2011, 15, 415-446. [CrossRef]

35. Masud, A.K.; Nurunnabi, M.; Bae, S.M. The effects of corporate governance on environmental sustainability reporting: Empirical evidence from South Asian countries. Asian J. Sustain. Soc. Responsib. 2018, 3. [CrossRef]

36. United Nations-Sustainable Development Goals. Available online: https://www.un.org/ sustainabledevelopment/sustainable-development-goals/ (accessed on 25 January 2020).

37. Ionascu, M.; Ionascu, I.; Sacarin, M.; Minu, M. Women on Boards and financial performance: Evidence from a European Emerging Market. Sustainability 2018, 10, 1644. [CrossRef]

38. Wang, Y.-H. Does Board Gender Diversity Bring Better Financial and Governance Performances? An Empirical Investigation of Cases in Taiwan. Sustainability 2020, 12, 3205. [CrossRef]

39. Carter, D.; D'Souza, F.; Simkins, B.; Simpson, C. The gender and ethnic diversity of US Boards and Board Committee and firm financial performance. Corp. Gov. Int. Rev. 2010, 18, 394-414. [CrossRef]

40. Bostan, I.; Grosu, V. The Role of Internal Audit in Optimization of Corporate Governance at the Groups of Companies. Theor. Appl. Econ. 2010, 17, 63-84.

41. Domil, A.E.; Artene, A.; Pavel, C.D. International Harmonization of Accounting Standards for Multinational Entities. An. Ser. Stiinte Econ. 2012, 18, 350-356. 
42. Paunescu, M. Guvernanța Corporativă, Managementul Riscurilor și Controlul Intern, Course Support of The Body of Licensed Accountants and Expert Accountants in Romania; CECCAR Publishing House: Bucharest, Romania, 2019.

43. Aldamen, H.; Duncan, K.; Kelly, S.; McNamara, R.; Ngel, S. Audit committe characteristics and firm performance during the global financial crisis. Account. Financ. 2012, 971-1000. [CrossRef]

44. Laing, D.; Weir, C. Governance structures, size and corporate performance in UK firms. Manag. Decis. 1999, 37, 457-464. [CrossRef]

45. Weir, C.; Laing, D. Governance structures, director independence and corporate performance in UK. Eur. Bus. Rev. 2001, 13, 86-95. [CrossRef]

46. Beisland, L.A.; Mersland, R.; Oystein Strom, R. Audit Quality and Corporate Governance: Evidence from the Microfinance Industry. Int. J. Audit. 2015, 19. [CrossRef]

47. Manita, R.; Elommal, N.; Baudier, P.; Hikkerova, L. The digital transformation of external audit and its impact on corporate governance. Technol. Forecast. Soc. Chang. 2020, 150. [CrossRef]

48. Conheady, B.; Mcilkenny, P.; Opong, K.; Pignatel, I. Board effectiveness and firm performance of Canadian listed firms. Br. Account. Rev. 2015, 47, 3290-3303. [CrossRef]

49. Bucharest Stock Exchange. Available online: https://www.bvb.ro/ (accessed on 2 February 2020).

50. Athex Stock Exchange. Available online: https://www.athexgroup.gr/ (accessed on 10 March 2020).

51. London Stock Exchange. Available online: https://www.londonstockexchange.com/ (accessed on 2 May 2020).

52. Madrid Stock Exchange. Available online: https://www.bolsamadrid.es/esp/aspx/Portada/Portada.aspx (accessed on 5 June 2020).

53. Warsaw Stock Exchange. Available online: https://www.gpw.pl/en-home (accessed on 25 June 2020).

54. Eurostat Statistics. Available online: https://ec.europa.eu/eurostat/databrowser/view/TEC00114/bookmark/ table?lang=en\&bookmarkId=388837b6-18d3-422f-8339-fa23f0378454 (accessed on 10 April 2020).

55. Onofrei, M.; Gavrilută, A.; Bostan, I.; Oprea, F.; Paraschiv, G.; Lazăr, C.M. The Implication of Fiscal Principles and Rules on Promoting Sustainable Public Finances in the EU Countries. Sustainability 2020, 12, 2772. [CrossRef]

56. Masud, A.K.; Bae, S.M.; Manzanares, J.; Kim, J.D. Board Directors Expertise and Corporate Corruption Disclosures: The Moderating Role of Political Connections. Sustainability 2019, 11, 4491. [CrossRef]

57. Perrini, F.; Rossi, G.; Rovetta, B. Does ownership structure affect performance? Evidence from the Italian market. Corp. Gov. Int. Rev. 2008, 16, 312-325. [CrossRef]

58. Angelakis, G.; Theriou, N.; Floropoulos, I.; Mandilas, A. Traditional and Currently Developed Management Accounting Practices-A Greek Study. Int. J. Econ. Bus. Admin. 2015, 3, 52-87. [CrossRef]

59. Linck, J.; Netter, J.; Yang, T. The determinants of board structure. Financ. Econ. 2008, 87, 308-328. [CrossRef]

60. Erhardt, N.; Werbel, J.; Shrader, C. Board of directors diversity and firm financial performance. Corp. Gov. Int. Rev. 2003, 11, 102-111. [CrossRef]

61. Bart, C.; McQueen, G. Why women make better directors? Int. J. Bus. Gov. Ethics 2013, 8, 93-99. [CrossRef]

62. De Andres, P.; Azofra, V.; Lopez, F. Corporate boards in OECD Countries: Size composition, functioning and effectiveness. Corp. Gov. Int. Rev. 2005, 13, 197-210. [CrossRef]

63. Moraru, M.; Franca, D. The importance of materiality in audit. An. Ser. Stiinte Econ. 2012, 18, 266.

64. Bajra, U.; Čadež, S. Audit committees and financial reporting quality: The 8th EU Company Law Directive perspective. Econ. Syst. 2018, 42, 151-163. [CrossRef]

65. Al-Ajmi, J. Audit firm, corporate governance, and audit quality: Evidence from Bahrain. Adv. Account. 2009, 25, 64-74. [CrossRef]

66. Chau, G.; Grey, S. Family ownership, board independence and voluntary disclosures: Evidence from Hong Kong. J. Int. Account. Audit. Tax. 2010, 19, 93-109. [CrossRef]

67. Chan, K.C.; Li, J. Audit committee and firm value: Evidence on outside top executives as expert-independent directors. Corp. Gov. Int. Rev. 2008, 16, 16-31. [CrossRef]

68. Hussain, N.; Rigoni, U.; Orij, R. Corporate governance and sustainability performance: Analysis of triple bottom line performance. J. Bus. Ethics 2018, 149, 411-432. [CrossRef]

69. Said, R.; Zainuddin, Y.H.; Haron, H. The relationship between corporate social responsibility disclosure and corporate governance characteristics in Malaysian public listed companies. Soc. Responsib. J. 2009, 5, $212-226$. [CrossRef] 
70. Nguyen, T.; Locke, S.; Reddy, K. A dynamic estimation of governance structures and financial performance for Singaporean companies. Econ. Model. 2014, 40,1-11. [CrossRef]

71. Guest, P.M. The impact of board size on firms performance: Evidence from UK. Eur. J. Financ. 2009, 15, 385-404. [CrossRef]

72. Crisan, A.R.; Fulop, M.T. The role of the audit committee in corporate governance-case study for a sample of companies listed on BSE and the London Stock Exchange-FTSE 100. Proc. Econ. Financ. 2014, 14, 1033-1041. [CrossRef]

73. Tai, V.; Lai, Y.; Yang, T. The role of the board and the audit committee in corporate risk management. N. Am. J. Econ. Financ. 2018, 100879. [CrossRef]

74. Mates, D.; Grosu, V.; Hlaciuc, E.; Bostan, I.; Bunget, O.; Domil, A.; Moraru, M.; Artene, A. Biological assets and the agricultural products in the context of the implementation of the IAS 41: A case study of the Romanian agro-food system. Arch. Biol. Sci. 2015, 67, 705-714. [CrossRef]

75. Lee, C.F.; Chen, H.Y.; Lee, J. Financial Econometrics, Mathematics and Statistics; Theory, Method and Application; Springer: Berlin/Heidelberg, Germany, 2019.

76. Bostan, I.; Lazăr, C.M.; Asalos, N. Legislative Means Aimed at Stimulating Green Procurement in the Public Sector. A Critical Case Study of Romania. Amfiteatru Econ. 2020, 22, 221-238. [CrossRef]

77. Asalos, N.; Vasile, I. Conceptual Aspects and a New Vision of Competitiveness in Actual Economic Context. Ovidius Univ. Ann. Ser. Econ. Sci. 2015, 15, 439-443.

78. Cioca, I.-L.; Ivascu, L.; Rada, C.; Torretta, V.; Ionescu, G. Sustainable Development and Technological Impact on $\mathrm{CO}_{2}$ Reducing Conditions in Romania. Sustainability 2015, 7, 1637-1650. [CrossRef]

Publisher's Note: MDPI stays neutral with regard to jurisdictional claims in published maps and institutional affiliations. 